NBER WORKING PAPER SERIES

\title{
SYSTEMATIC RISK, DEBT MATURITY, AND THE TERM STRUCTURE OF CREDIT SPREADS
}

\section{Hui Chen}

$\mathrm{Yu} \mathrm{Xu}$

Jun Yang

Working Paper 18367

http://www.nber.org/papers/w18367

\author{
NATIONAL BUREAU OF ECONOMIC RESEARCH \\ 1050 Massachusetts Avenue \\ Cambridge, MA 02138 \\ September 2012
}

We thank Viral Acharya, Heitor Almeida, Jennifer Carpenter, Chris Hennessy, Burton Holliéld, Nengjiu Ju, Thorsten Koeppl, Leonid Kogan, Jun Pan, Monika Piazzesi, Ilya Strebulaev, Wei Xiong and seminar participants at the NBER Asset Pricing Meeting, Texas Finance Festival, China International Conference in Finance, Summer Institute of Finance Conference, Bank of Canada Fellowship Workshop, London School of Economics, and London Business School for comments. The views expressed herein are those of the authors and do not necessarily reflect the views of the National Bureau of Economic Research.

NBER working papers are circulated for discussion and comment purposes. They have not been peerreviewed or been subject to the review by the NBER Board of Directors that accompanies official NBER publications.

(C) 2012 by Hui Chen, Yu Xu, and Jun Yang. All rights reserved. Short sections of text, not to exceed two paragraphs, may be quoted without explicit permission provided that full credit, including $\odot$ notice, is given to the source. 
Systematic Risk, Debt Maturity, and the Term Structure of Credit Spreads

Hui Chen, Yu Xu, and Jun Yang

NBER Working Paper No. 18367

September 2012

JEL No. E32,G32,G33

\begin{abstract}
We build a dynamic capital structure model to study the link between firms' systematic risk exposures and their time-varying debt maturity choices, as well as its implications for the term structure of credit spreads. Compared to short-term debt, long-term debt helps reduce rollover risks, but its illiquidity raises the costs of financing. With both default risk and liquidity costs changing over the business cycle, our calibrated model implies that debt maturity is pro-cyclical, firms with high systematic risk favor longer debt maturity, and that these firms will have more stable maturity structures over the cycle. Moreover, pro-cyclical maturity variation can significantly amplify the impact of aggregate shocks on the term structure of credit spreads, especially for firms with high beta, high leverage, or a lumpy maturity structure. We provide empirical evidence for the model predictions on both debt maturity and credit spreads.
\end{abstract}

Hui Chen

MIT Sloan School of Management

77 Massachusetts Avenue, E62-637

Cambridge, MA 02139

and NBER

huichen@mit.edu

$\mathrm{Yu} \mathrm{Xu}$

Massachusetts Institute of Technology

77 Massachusetts Ave

Cambridge, MA 02139

yu_xu@mit.edu
Jun Yang

Bank of Canada

junyang@bankofcanada.ca 


\section{Introduction}

The aggregate corporate debt maturity has a clear cyclical pattern: the average debt maturity is longer in economic expansions than in recessions. Using data from the Flow of Funds Accounts, we plot in Figure 1 the trend and cyclical components of the share of long-term debt for nonfinancial firms from 1952 to 2010. There is distinct pro-cyclical variation in the aggregate long-term debt share, with the cyclical component dropping by $4 \%$ on average from peak to trough. ${ }^{1}$ These facts raise important questions for firms' debt maturity management and corporate bond pricing. First, how do firms with different exposures to aggregate risks make their debt maturity choices? Second, given that a reduction of the debt maturity typically leads to higher rollover risk, how much can the cyclical variation in debt maturity amplify the fluctuations in credit risk over the business cycle?

Our paper addresses these two questions using a dynamic capital structure model with maturity choice. The model not only endogenously determines firms' default risk for a given maturity choice, but also shows how firms can manage their systematic risk exposures through optimal maturity choice. In the model, firms face business cycle fluctuations in growth, economic uncertainty, and risk premia. They choose how much debt to issue based on the trade-off between the tax benefits of debt and the costs of financial distress. Default occurs due to equity holders' inability to commit to servicing the debt, especially when debt needs to be rolled over at high yields. A longer debt maturity helps reduce this rollover risk. At the same time, long-term bonds are more costly to issue than short-term bonds due to their illiquidity, which we model in reduced form and calibrate to the data. Firms choose their debt maturity based on these trade-offs.

In the model, systematic risk affects maturity choice through two channels. For firms with high systematic risk, default is more likely to occur in aggregate bad times. Since the risk premium associated with the deadweight losses of default raises the expected bankruptcy costs, these firms choose longer debt maturity during normal times to reduce rollover risk,

\footnotetext{
${ }^{1}$ The sample mean of long-term debt share is $62 \%$. We do not study the long-term trend in debt maturity in this paper. Greenwood, Hanson, and Stein (2010) argue that this trend is consistent with firms acting as macro liquidity providers.
} 
A. Long term debt share trend
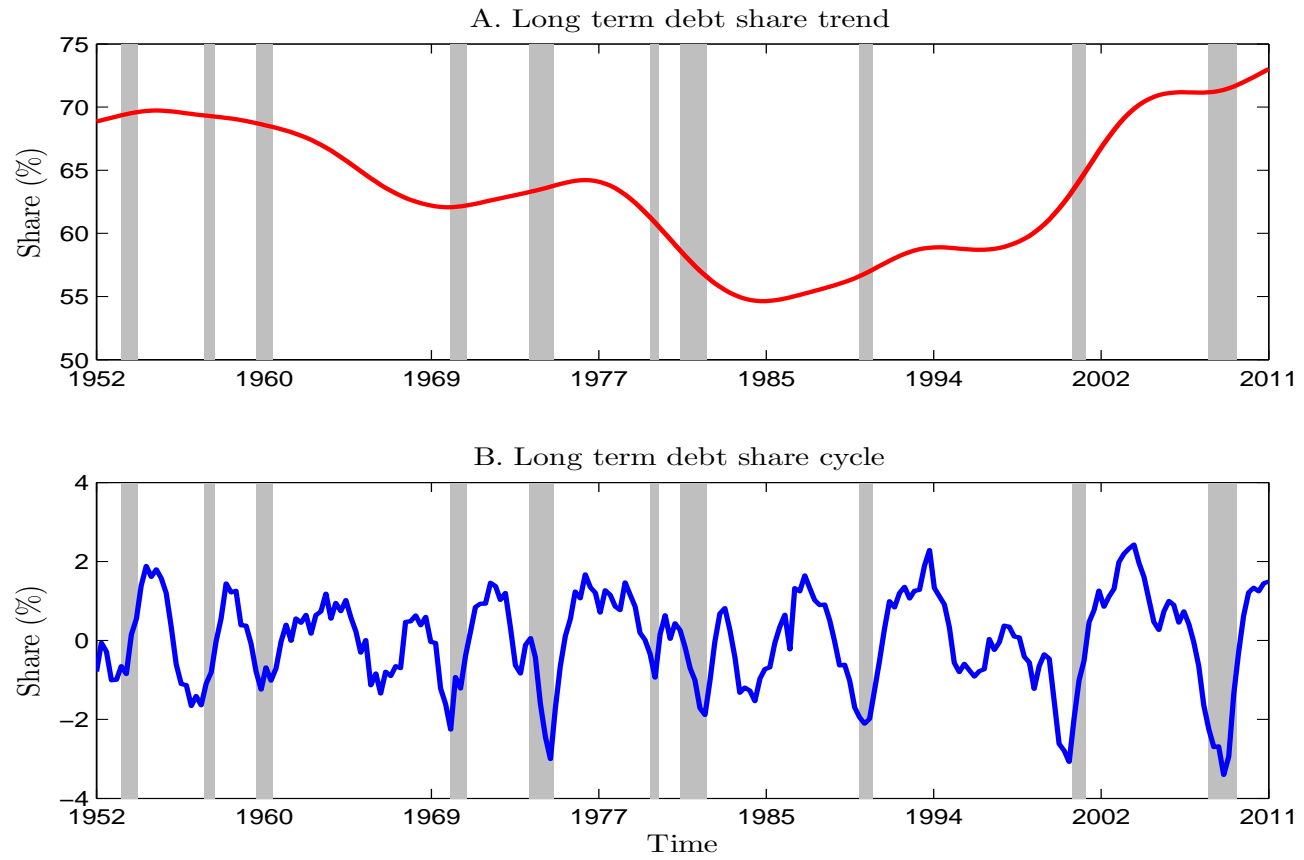

Figure 1: Long-term debt share for nonfinancial corporate business. The top panel plots the trend component (via the Hodrick-Prescott filter) of aggregate long-term debt share. The bottom panel plots the cyclical component. The shaded areas denote NBER-dated recessions. Source: Flow of Funds Accounts (Table L.102).

which in turn lowers their default risk and bankruptcy costs. Next, in recessions, risk premium rises, and so does the liquidity premium for long-term bonds. On the one hand, firms with low systematic risk exposures respond by replacing the long-term bonds that is maturing in recessions with short-term bonds, which lowers their average debt maturity. On the other hand, firms with high systematic risk become even more concerned about the rollover risk associated with short maturity during such times. In response, they continue rolling over the matured long-term bonds into new long-term bonds despite the higher liquidity costs. As a result, their maturity structures are more stable over the business cycle than firms with low systematic risk.

Our calibrated model generates reasonable predictions for leverage, default probabilities, credit spreads, and equity pricing. Through the model, we also analyze the impact of debt maturity dynamics on the term structure of credit spreads. 
First, compared to the case of a time-invariant maturity structure, pro-cyclical maturity variation raises a firm's default risk and amplifies the fluctuations in its credit spreads over the business cycle. As a result, ignoring the maturity dynamics can lead one to severely underestimate the credit risk of firms. The amplification effect of maturity dynamics is nonlinear and differs significantly across firms. Based on our calibration, for a low-leverage firm, a moderate reduction in debt maturity from 5.5 years to 5 years in a recession has almost no effect on the credit spreads, whereas reducing the maturity to 1 year can cause the credit spreads to rise by up to 100 bps. Such drastic reductions in maturity are particularly relevant when firms have lumpy maturity structures, where maturity can change quickly if the recession arrives just as a large amount of long-term debt is coming due. Moreover, the amplification effect is stronger for firms with high beta or high leverage.

Second, the maturity dynamics affect different parts of the term structure of credit spreads differently depending on firm-specific and macroeconomic conditions. For firms with low leverage, while a reduction in debt maturity raises rollover risk over time (i.e., for future states with low cash flows), it is unlikely to cause solvency problem in the short run. Thus, the maturity dynamics mainly affect the medium maturity of the credit spread curve and almost have no impact on the short end of the curve. In contrast, for firms with high leverage, the effect of the maturity reduction on credit risk is not only much stronger, but is concentrated at the short end of the credit spread curve, which reflects the imminent threat of rollover risk.

Third, our model shows that the endogenous link between systematic risk and debt maturity should be a key consideration for empirical studies of rollover risk. Firms with high systematic risk endogenously choose longer debt maturity and more stable maturity structures over time. However, their credit spreads (as well as earnings and investment) will likely still be more affected by aggregate shocks because these firms are fundamentally more exposed to aggregate risk. Thus, instead of identifying high-rollover risk firms simply by comparing at the levels or changes in debt maturity, one should account for the heterogeneity in firms' systematic risk exposures.

We test the model predictions using firm-level data from 1974 to 2010. Consistent with the model, we find that firms with high systematic risk choose longer debt maturity and 
maintain a more stable maturity structure over the business cycle. After controlling for total asset volatility and leverage, a one-standard deviation increase in asset market beta raises firm's long-term debt share (the percentage of total debt that matures in more than 3 years) by $6.5 \%$. When macroeconomic conditions worsen, for example, in recessions or during times of high market volatility, the average debt maturity falls, while the sensitivity of debt maturity to systematic risk exposure becomes higher. The long-term debt share is $3.7 \%$ lower in recessions than in expansions for a firm with asset market beta at the 10th percentile, but almost unchanged for a firm with asset beta at the 90th percentile. These findings are robust to different measures of systematic risk and different proxies for debt maturity. Furthermore, using data from the recent financial crisis, we find that the effects of rollover risk on credit spreads are significantly stronger for firms with high leverage or high beta, and are stronger for shorter maturity, which are again consistent with our model.

The main contribution of our paper is two-fold. First, it provides both a theory and empirical evidence for the link between systematic risk and firms' maturity choices in the cross section and over time. It adds to the growing body of research on how aggregate risk affects corporate financing decisions, which includes Almeida and Philippon (2007), Acharya, Almeida, and Campello (2012), Bhamra, Kuehn, and Strebulaev (2010a), Bhamra, Kuehn, and Strebulaev (2010b), Chen (2010), Chen and Manso (2010), and Gomes and Schmid (2010), among others.

On the empirical side, Barclay and Smith (1995) find that firms with higher asset volatility choose shorter debt maturity. They do not separately examine the effects of systematic and idiosyncratic risk on debt maturity. Baker, Greenwood, and Wurgler (2003) argue that firms time the market by looking at inflation, the real short-term rate, and the term spread to determine the maturity that minimizes the cost of capital. Two recent empirical studies have documented that firms' debt maturity changes over the business cycle. Erel, Julio, Kim, and Weisbach (2012) show that new debt issuances shift towards shorter maturity and more security during times of poor macroeconomic conditions. Mian and Santos (2011) show that the effective maturity of syndicated loans is pro-cyclical, especially for credit worthy firms. They also argue that firms actively managed their loan maturity before the financial crisis 
through early refinancing of outstanding loans. Our measure of systematic risk exposure is distinct from their measures of credit quality.

Second, our paper contributes to the studies of the term structure of credit spreads. ${ }^{2}$ Structural models can endogenously link default risk to firms' financing decisions, such as leverage and maturity structure. This is valuable for credit risk modeling, because while intuitive, it is far from obvious how debt maturity actually affects credit risk at different horizons. For simplicity, earlier models mostly restrict the maturity structure to be timeinvariant. Our model allows the maturity structure to change over the business cycle, which demonstrates how systematic risk affects the dynamics of maturity choice, and how the maturity choice in turn affects the term structure of credit risk.

Furthermore, our model can capture lumpiness in the maturity structure. This feature is prevalent in practice (see Choi, Hackbarth, and Zechner (2012)). In their study of the real effects of financial frictions, Almeida, Campello, Laranjeira, and Weisbenner (2011) exploit this feature to identify firms most exposed to rollover risk. Our model shows that lumpiness in the maturity structure interacted with time-varying macroeconomic conditions has rich implications for credit risk.

Our model builds on the dynamic capital structure models with optimal choices for leverage, maturity, and default decisions. The disadvantage of short-term debt in these models is that debt rollover causes excessive liquidation. Possible costs for long-term debt include illiquidity (He and Milbradt (2012)), information asymmetry and adverse selection (Diamond (1991), Flannery (1986)), or agency problems (Leland and Toft (1996)). We focus on the cost of illiquidity because it can be directly calibrated to the data. Bao, Pan, and Wang (2011), Chen, Lesmond, and Wei (2007), Edwards, Harris, and Piwowar (2007), and Longstaff, Mithal, and Neis (2005) have all documented a significant positive relation between maturity and various measures of corporate bond illiquidity.

\footnotetext{
${ }^{2}$ Earlier contributions include structural models by Chen, Collin-Dufresne, and Goldstein (2009), CollinDufresne and Goldstein (2001), Duffie and Lando (2001), Leland (1994), Leland and Toft (1996), Zhou (2001), and reduced-form models by Duffie and Singleton (1999), Jarrow, Lando, and Turnbull (1997), Lando (1998), among others.
} 


\section{Model}

In this section, we present a dynamic capital structure model that captures the link between systematic risk and debt maturity.

\subsection{The Economy and The Firm}

The state of the aggregate economy is described by a two-state, continuous-time Markov chain with the state at time $t$ denoted by $s_{t} \in\{G, B\}$. State $G$ represents an expansion state, which is characterized by high expected growth rates, low economic uncertainty, and low risk premium, while the opposite is true in the recession state $B$. The physical transition intensities from state $G$ to $B$ and from $B$ to $G$ are $\pi_{G}^{\mathbb{P}}$ and $\pi_{B}^{\mathbb{P}}$, respectively, which implies that between $t$ and $t+\Delta$, the economy will switch from state $G$ to $B$ ( $B$ to $G$ ) with probability $\pi_{G}^{\mathbb{P}} \Delta\left(\pi_{B}^{\mathbb{P}} \Delta\right)$ approximately. In addition, it implies that the stationary probability of the expansion state is $\pi_{B}^{\mathbb{P}} /\left(\pi_{G}^{\mathbb{P}}+\pi_{B}^{\mathbb{P}}\right)$.

We assume there exists an exogenous stochastic discount factor (SDF) $\Lambda_{t}:^{3}$

$$
\frac{d \Lambda_{t}}{\Lambda_{t^{-}}}=-r\left(s_{t^{-}}\right) d t-\eta\left(s_{t^{-}}\right) d Z_{t}^{\Lambda}+\delta_{G}\left(s_{t^{-}}\right)\left(e^{\kappa}-1\right) d M_{t}^{G}-\delta_{B}\left(s_{t^{-}}\right)\left(1-e^{-\kappa}\right) d M_{t}^{B},
$$

with

$$
\delta_{G}(G)=\delta_{B}(B)=1, \quad \delta_{G}(B)=\delta_{B}(G)=0,
$$

where $r\left(s_{t}\right)$ is the state-dependent risk free rate, and $\eta\left(s_{t}\right)$ is the market price of risk for the aggregate Brownian shocks $d Z_{t}^{\Lambda}$. The compensated Poisson processes $d M_{t}^{s_{t}}=d N_{t}^{s_{t}}-\pi_{s_{t}}^{\mathbb{P}} d t$ capture the changes of the aggregate state (away from state $s_{t}$ ), while $\kappa$ determines the size of the jump in the discount factor when the aggregate state changes. To capture the notion that state $B$ is a time with high marginal utilities and high risk prices, we set $\eta(B)>\eta(G)$ and set $\kappa>0$ so that $\Lambda_{t}$ jumps up going into a recession and down coming out of a recession.

\footnotetext{
${ }^{3}$ See Chen (2010) for a general equilibrium model based on the long-run risk model of Bansal and Yaron (2004) that generates the stochastic discount factor of this form.
} 
A firm generates cash flows $y_{t}$, which follow the process

$$
\frac{d y_{t}}{y_{t}}=\mu^{\mathbb{P}}\left(s_{t}\right) d t+\sigma_{\Lambda}\left(s_{t}\right) d Z_{t}^{\Lambda}+\sigma_{f}\left(s_{t}\right) d Z_{t}^{f}
$$

The standard Brownian motion $Z_{t}^{f}$ is independent of $Z_{t}^{\Lambda}$ and is the source of firm-specific cash-flow shocks. The expected growth rate of cash flows is $\mu^{\mathbb{P}}\left(s_{t}\right)$, while $\sigma_{\Lambda}\left(s_{t}\right)$ and $\sigma_{f}\left(s_{t}\right)$ denote the systematic and idiosyncratic conditional volatility of cash flows, respectively. Although a change in the aggregate state $s_{t}$ does not lead to any immediate change in the level of cash flows, it changes the dynamics of $y_{t}$ by altering its conditional growth rate and volatilities.

Valuation is convenient under the risk-neutral probability measure $\mathcal{Q}$. The SDF in (1) implies the risk-neutral dynamics of cash flows:

$$
\frac{d y_{t}}{y_{t}}=\mu\left(s_{t}\right) d t+\sigma\left(s_{t}\right) d Z_{t}
$$

where $Z_{t}$ is a standard Brownian motion under $\mathcal{Q}$. The risk-neutral expected growth rate of cash flows is $\mu\left(s_{t}\right)=\mu^{\mathbb{P}}\left(s_{t}\right)-\sigma_{\Lambda}\left(s_{t}\right) \eta\left(s_{t}\right)$, and $\sigma\left(s_{t}\right)=\sqrt{\sigma_{\Lambda}^{2}\left(s_{t}\right)+\sigma_{f}^{2}\left(s_{t}\right)}$ is total volatility of cash flows. The adjustment for the expected growth rate is quite intuitive. Cash flows are risky if they are negatively correlated with the stochastic discount factor $\left(\sigma_{\Lambda}\left(s_{t}\right) \eta\left(s_{t}\right)>0\right)$. For valuation under $\mathcal{Q}$, we account for the risks of cash flows by lowering the expected growth rate, which has the same effect as adding a risk premium to the discount rate.

In addition to the cash flow process, the risk-neutral transition intensities between the aggregate states are given by $\pi_{G}=e^{\kappa} \pi_{G}^{\mathbb{P}}$ and $\pi_{B}=e^{-\kappa} \pi_{B}^{\mathbb{P}}$. Because $\kappa>0$, the risk-neutral transition intensity from state $G$ to $B$ is higher than the physical intensity, while the riskneutral intensity from state $B$ to $G$ is lower than the physical intensity. Jointly, they imply that the bad state is both more likely to occur and longer lasting under the risk-neutral measure than under the physical measure. 
Without any taxes, the value of an unlevered firm, $V(y, s)$, satisfies a system of ODEs:

$$
r(s) V(y, s)=y+\mu(s) y V_{y}(y, s)+\frac{1}{2} \sigma^{2}(s) y^{2} V_{y y}(y, s)+\pi_{s}\left(V\left(y, s^{c}\right)-V(y, s)\right)
$$

where $s^{c}$ denotes the complement state to state $s$. Its solution is $V(y, s)=v(s) y$, where $\mathbf{v} \equiv(v(G), v(B))$ is given by

$$
\mathbf{v}=\left(\begin{array}{cc}
r(G)-\mu(G)+\pi_{G} & -\pi_{G} \\
-\pi_{B} & r(B)-\mu(B)+\pi_{B}
\end{array}\right)^{-1}\left(\begin{array}{l}
1 \\
1
\end{array}\right)
$$

This is a generalized Gordon growth formula, which takes into account the state-dependent riskfree rates and risk-neutral expected growth rates, as well as possible future transitions between the states. In the special case of no transition between the states $\left(\pi_{G}=\pi_{B}=0\right)$, Equation (5) reduces to the standard Gordon growth formula $v(s)=(r(s)-\mu(s))^{-1}$.

\subsection{Capital Structure}

Firms in our model choose optimal leverage and debt maturity jointly. The optimal leverage is primarily determined by the trade-off between the tax benefits (interest expenses are tax-deductible) and bankruptcy costs of debt. The effective tax rate on corporate income is $\tau$. In bankruptcy, debt-holders recover a fraction $\alpha(s)$ of the firm's unlevered assets while equity-holders receive nothing. For the maturity choice, firms trade off the rollover risk of short-term debt against the costs of illiquidity for long-term debt.

To fully specify a maturity structure, one needs to specify the amount of debt due at different horizons as well as the rollover policy when debt matures. Leland and Toft (1996) and Leland (1998) model static maturity structures: debt matures at a constant rate over time, and the average maturity for all existing debt also remains constant. For example, Leland (1998) assumes that debt has no stated maturity but is continuously retired at face

value at a constant rate $m$, and that all retired debt is replaced by new debt with identical face value and seniority. This implies that the average maturity of debt outstanding today 
is $\int_{0}^{\infty} t m e^{-m t} d t=1 / m$. Such a maturity structure rules out the possibility of dynamic adjustment in maturity, which is an important feature in the data (see Figure 1). A uniform maturity structure also rules out "lumpiness", in particular, the possibility of having a large amount of debt retiring in a short period of time. Choi, Hackbarth, and Zechner (2012) find that lumpiness in debt maturity is commonly observed, which could be for the purpose of lowering floatation costs, improving liquidity, or market timing.

We first extend the maturity structure in Leland (1998) by allowing a firm to roll over its retired debt into new debt of different maturity when the state of the economy changes. Consider the following setting. Let the maturity structure in state $G$ (good times) be the same as in Leland (1998): debt is retired at a constant rate $m_{G}$ and is replaced by new debt with the same principal value and seniority. When state $B$ (recession) arrives, the firm can choose to replace the retired debt with new debt of a different maturity (still with the same seniority). This new maturity is determined by the rate $\bar{m}_{B}$ at which the new debt is retired. Thus, the firm will have two types of debt outstanding in state $B$, one with average maturity of $1 / m_{G}$ and the other with average maturity $1 / \bar{m}_{B}$ (conditional on being in state $B$ ). After $t$ years in state $B$, the instantaneous rate of debt retirement is $R_{B}(t)=m_{G} e^{-m_{G} t}+\bar{m}_{B}\left(1-e^{-m_{G} t}\right)$. Finally, when the economy moves from state $B$ back to state $G$, the firm swaps all the type- $\bar{m}_{B}$ debt into type- $m_{G}$ debt.

The time dependence of $R_{B}(t)$ makes the problem less tractable. Instead, we approximate the above dynamics by assuming that all debt will be retired a constant rate $m_{B}$ in state $B$, where $m_{B}$ is the average rate of debt retirement in state $B$ :

$$
m_{B}=\int_{0}^{\infty} \pi_{B}^{\mathbb{P}} e^{-\pi_{B}^{\mathbb{P}} t}\left(\frac{1}{t} \int_{0}^{t} R_{B}(u) d u\right) d t .
$$

Thus, choosing $m_{B}$ will be approximately equivalent to choosing $\bar{m}_{B}$ as long as the value of $\bar{m}_{B}$ implied by (6) is nonnegative. Since debt will be retired at a constant rate in both states based on this approximation, we define the firm's average debt maturity conditional on the state as $M_{s}=1 / m_{s}$.

Based on this interpretation of maturity dynamics, the choice of capital structure can 
be characterized by the 4 -tuple $\left(P, C, m_{G}, m_{B}\right)$, where $P$ is the face value of debt and $C$ is the (instantaneous) coupon rate. The default policy, which is chosen by equity-holders ex post, is determined by a pair of default boundaries $\left\{y_{D}(G), y_{D}(B)\right\}$. In a given state, the firm defaults if its cash flow is below the default boundary for that state. As shown in Chen (2010), because the default boundary is different in the two states, default can either be triggered by small shocks that drive the cash flow below the default boundary, or by a change in the state that raises the default boundary above the cash flow.

Using data on the credit spreads for corporate bonds and credit default swaps (CDS), Longstaff, Mithal, and Neis (2005) identify the non-default component in corporate bond yields. They find a strong positive relation between corporate bond maturity and the nondefault component. He and Milbradt (2012) provide a model that endogenously link the corporate bond liquidity spread to maturity. Motivated by these studies, we model the illiquidity of long-term bonds in reduced form by positing a non-default spread, $\ell\left(m, s_{t}\right)$, at which debt is priced by the market. Specifically, we assume

$$
\ell\left(m, s_{t}\right)=\ell_{0}(s)\left(e^{\ell_{1}(s) / m}-1\right) .
$$

With positive values for $\ell_{0}$ and $\ell_{1}$, the non-default spread will be increasing with maturity (decreasing in $m$ ), and the spread goes to 0 when maturity approaches 0 ( $m$ goes to infinity). In addition, we allow the non-default spread to depend on the aggregate state. In particular, for the same maturity, the spread can be higher in the bad state: $\ell(\cdot, B)>\ell(\cdot, G)$.

The time- $t$ market value of all the debt that is issued at time $0, D^{0}(t, y, s)$, satisfies a system of partial differential equations:

$$
\begin{aligned}
\left(r(s)+\ell\left(m_{s}, s\right)\right) D^{0}(t, y, s)= & e^{-\int_{0}^{t} m_{s u} d u}\left(C+m_{s} P\right)+D_{t}^{0}(t, y, s)+\mu(s) y D_{y}^{0}(t, y, s) \\
& +\frac{1}{2} \sigma^{2}(s) y^{2} D_{y y}^{0}(t, y, s)+\pi_{s}\left(D^{0}\left(t, y, s^{c}\right)-D^{0}(t, y, s)\right)
\end{aligned}
$$

where $e^{-\int_{0}^{t} m_{s_{u}} d u}$ gives the fraction of original debt that has not retired by time $t$. The term involving the non-default spread, $\ell(m, s) D^{0}(t, y, s)$, can be interpreted as a per-period holding 
cost for anyone investing in corporate bonds or the costs that investors incur when they are exposed to idiosyncratic and non-diversifiable liquidity shocks as modeled in He and Milbradt (2012). At bankruptcy, the value of these debt will be equal to a fraction $e^{-\int_{0}^{t} m_{s u} d u}$ of the total recovery value.

As in Leland (1998), the value of total debt outstanding at time $t, D\left(y_{t}, s_{t}\right)$, will be independent of $t$. It satisfies the following system of ordinary differential equations:

$$
\begin{aligned}
\left(r(s)+\ell\left(m_{s}, s\right)\right) D(y, s)= & C+m_{s}(P-D(y, s))+\mu(s) y D_{y}(y, s) \\
& +\frac{1}{2} \sigma^{2}(s) y^{2} D_{y y}(y, s)+\pi_{s}\left(D\left(y, s^{c}\right)-D(y, s)\right),
\end{aligned}
$$

with boundary condition at default:

$$
D\left(y_{D}(s), s\right)=\alpha(s) v(s) y_{D}(s),
$$

where $v(s)$ is the price-to-cash-flow ratio given in (5). Everything else equal, adding the non-default spread lowers the market value of debt, which is a form of financing costs that will affect equity-holders' financing decisions.

Next, the value of equity, $E(y, s)$, satisfies:

$$
\begin{aligned}
r(s) E(y, s)= & (1-\tau)(y-C)-m_{s}(P-D(y, s))+\mu(s) y E_{y}(y, s) \\
& +\frac{1}{2} \sigma(s)^{2} y^{2} E_{y y}(y, s)+\pi_{s}\left(E\left(y, s^{c}\right)-E(y, s)\right) .
\end{aligned}
$$

For simplicity, we assume that equity is discounted at the riskfree rate $r(s)$, i.e. there is no additional liquidity discount for equity valuation. This is consistent with the fact that equity markets are typically significantly more liquid than corporate bond markets.

The first two terms on the right-hand side of equation (11) give the instantaneous net cash flow accruing to equity holders of an ongoing firm. The first term is the cash flow net of interest expenses and taxes. The second term, $m_{s}(P-D(y, s))$, is the instantaneous rollover costs. If old bonds mature and are replaced by new bonds that are issued under par value 
$(D(y, s)<P)$, equity holders will have to incur extra costs for debt rollover.

The rollover costs depend on both firm-specific and macroeconomic conditions. For a firm with low cash flows $y_{t}$, its debt is more risky, and it will incur higher rollover costs. Under poor macroeconomic conditions, low expected growth rates of cash flows, high systematic volatility, and high liquidity spreads all tend to drive the market value of debt lower, which also raises the rollover costs. Finally, a shorter debt maturity means debt is retiring at a higher rate ( $m$ is large), which amplifies the rollover costs whenever debt is priced below par.

The boundary conditions for equity at default are:

$$
\begin{aligned}
E\left(y_{D}(s), s\right) & =0 \\
E_{y}\left(y_{D}(s), s\right) & =0
\end{aligned}
$$

The first condition states that equity value is zero at default. The second is the standard smooth-pasting condition, which ensures that the state-dependent default boundaries $y_{D}(s)$ are optimal.

The tradeoff between rollover risk and liquidity-related financing costs is influenced by leverage, systematic risk exposure, and macroeconomic conditions. All else equal, firms with low leverage or low exposure to systematic risk are less concerned about rollover risk. They will gravitate towards short-term debt to reduce financing costs. The opposite is true for highly levered firms or firms with high systematic risk exposures, who will prefer longer maturity debt despite the liquidity discount. These tradeoffs also vary over the business cycle. For example, rollover risk is a bigger concern in recessions because firms are closer to bankruptcy and the costs of bankruptcy are higher during such times.

Having discussed the value of debt and equity given the capital structure in place, we now state the firm's capital structure problem. At time $t=0,{ }^{4}$ the firm takes as given the pricing kernel $\Lambda_{t}$, the cash flow process $y_{t}$, the tax rate $\tau$, bankruptcy $\operatorname{costs} \alpha(s)$, and the non-default spreads for corporate bonds $\ell(m, s)$, and chooses its capital structure $\left(P, m_{G}, m_{B}\right)$ in order

\footnotetext{
${ }^{4}$ Our model can be extended to have dynamic adjustment in leverage, which have been shown by Strebulaev (2007) and Bhamra, Kuehn, and Strebulaev (2010a) to be important in understanding the time-series and cross-sectional properties of financial leverage.
} 
to maximize the initial value of the firm:

$$
\max _{P, m_{G}, m_{B}} E\left(y_{0}, s_{0} ; P, m_{G}, m_{B}\right)+D\left(y_{0}, s_{0} ; P, m_{G}, m_{B}\right) .
$$

We fix the coupon rate $C$ such that debt is priced at par at issuance. In addition, we have assumed that the firm can commit to its maturity policy $\left(m_{G}, m_{B}\right)$ chosen at time $t=0$. Alternatively, equity-holders can ex post choose when to adjust its debt maturity, which will depend on not only the aggregate state, but also the firm's cash flows.

The model we set up in this section has the necessary ingredients for us to examine how firms adjust their maturity structure over the business cycle. At the same time it is also quite tractable. For given choices of debt and default policy, we obtain closed-form expressions for the debt and equity value. We then solve for the optimal default boundaries via a system of non-linear equations. Finally, we solve for the optimal capital structure via (14). The details of the solution are in Appendix A.

\subsection{A Lumpy Maturity Structure}

In this section, we extend the baseline 2-state model to capture lumpy maturity structures, which is not only a common feature in the data, but can be a key determinant of firms' financial constraints (see Almeida, Campello, Laranjeira, and Weisbenner (2011)). We use this extension to demonstrate how dramatic maturity reductions can occur realistically, and how they affect the term structure of credit risk. Here we take the lumpy maturity structure as given. Choi, Hackbarth, and Zechner (2012) analyzes why firms might choose a lumpy maturity structure instead of a granular one.

A basic example of a lumpy maturity structure works as follows. At $t=0$, a firm issues a certain amount of debt with $T$ years to maturity. Each year before $T$ (assuming default has not occurred), the firm makes coupon payments but does not need to pay back any principal. At time $t=T$, all the principal of the debt issued at $t=0$ is paid back, and the firm issues new debt with the same principal and same maturity $T$ to replace the retired debt. This maturity cycle keeps repeating every $T$ years until default occurs. 


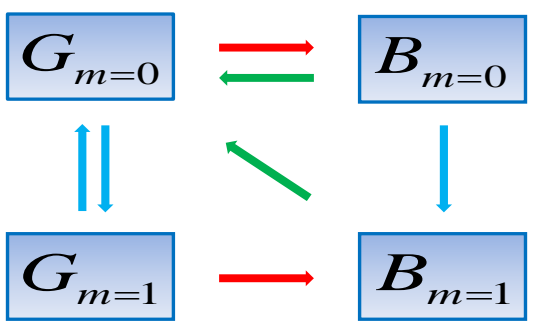

Figure 2: Illustration of the 4-state model. The graph illustrates the state transitions in the 4-state model that allows for lumpiness in the maturity structure.

The main challenge with capturing such a maturity structure is that it introduces time dependence, because the maturity of the debt outstanding changes mechanically as time passes. To capture the maturity cycle but avoid the time-dependence problem, we extend the model of Leland (1998) by introducing two maturity states. Again, debt is issued without stated maturity. In the first maturity state, no debt is retired, i.e., $m_{1}=0$. In the second maturity state, $m_{2}=1$, so that the amount of debt rolled over in one year will be equal to the total amount of debt outstanding. Compared to the $T$-year debt above, the first maturity state mimics the time when no debt is retiring, while the second maturity state mimics the time when all the debt retires. We then specify the transition intensities between the two maturity states such that the first state is expected to last for $T-1$ years, while the second state is expected to last for 1 year. ${ }^{5}$

Next, we model how the lumpy maturity structure is affected by changes in the state of the economy. Suppose issuing long-term debt becomes so costly in state $B$ that the firm only issues one-year debt in that state. In the aggregate state $G$, the firm follows the above two-state maturity cycle, with the two states denoted by $G_{m=0}$ and $G_{m=1}$. If the state of the economy changes while the firm is in state $G_{m=0}$, it is expected that no debt will be due for $T-1$ years (on average). This state is denoted as $B_{m=0}$. If the state of the economy changes while the firm is in state $G_{m=1}$, all debt effectively have average maturity of one

\footnotetext{
${ }^{5}$ There are many ways to generalize the setup. For example, we can make the second maturity state more transient and raise $m_{2}$ so that debt is rolled over more quickly.
} 
year and will continue to be rolled into one-year debt, i.e., $m=1$. We denote this state as $B_{m=1}$. The firm will be stuck in state $B_{m=1}$ until the aggregate state changes back to $G$, at which point we assume the firm buys back all the short-term debt and replaces them with new long-term debt. That is, it returns to state $G_{m=0}$. Figure 2 summarizes the dynamics across the maturity states. By extending the generator matrix for the two-state model, we obtain the transition intensities across the 4 states $\left\{G_{m=0}, G_{m=1}, B_{m=0}, B_{m=1}\right\}$ :

$$
\Pi=\left[\begin{array}{cccc}
-\left(\frac{1}{T-1}+\pi_{G}\right) & \frac{1}{T-1} & \pi_{G} & 0 \\
1 & -\left(1+\pi_{G}\right) & 0 & \pi_{G} \\
\pi_{B} & 0 & -\left(\pi_{B}+\frac{1}{T-1}\right) & \frac{1}{T-1} \\
\pi_{B} & 0 & 0 & -\pi_{B}
\end{array}\right]
$$

The solution to the 4-state model is similar to that of the 2-state model, the details of which are in Appendix A.

\section{Quantitative Analysis}

\subsection{Calibration}

Panel A of Table 1 summarizes the parameter values for our baseline model. The transition intensities for the aggregate states are given by $\pi_{G}^{\mathbb{P}}=0.1$ and $\pi_{G}^{\mathbb{B}}=0.5$, which imply that an expansion is expected to last for 10 years, while a recession is expected to last for 2 years. The stationary probabilities of being in an expansion and a recession are 5/6 and 1/6, respectively. To calibrate the stochastic discount factor, we calibrate the riskfree rate $r(s)$, the market prices of risk for Brownian shocks $\eta(s)$, and the market price of risk for state transition $\kappa$ to match their counterparts in the SDF in Chen (2010). ${ }^{6}$

Similarly, we calibrate the expected growth rate $\mu^{\mathbb{P}}(s)$ and systematic volatility $\sigma_{\Lambda}(s)$ for the benchmark firm based on Chen (2010), which in turn are calibrated to the data of corporate profits from the National Income and Product Accounts. The annualized

\footnotetext{
${ }^{6}$ For example, $r(G)$ and $r(B)$ are chosen to match the mean and volatility of riskfree rates in Chen (2010).
} 
idiosyncratic cash flow volatility of the benchmark firm is fixed at $\sigma_{f}=23 \%$. The bankruptcy recovery rates in the two states are $\alpha(G)=0.72$ and $\alpha(B)=0.59$. Such cyclical variations in the recovery rate have important effects on the ex ante bankruptcy costs. The effective tax rate $\tau=0.2$, which takes into account the fact that part of the tax advantage of debt at the corporate level is offset by individual tax disadvantages of interest income (see Miller (1977)). To define model-implied market betas, we specify the dividend process for the market portfolio using the levered cash-flow process (2) without idiosyncratic volatility. The leverage factor is chosen so that the unlevered market beta for the benchmark firm is 0.8 .

To calibrate the non-default term spread $\ell(m, s)$ specified in $(7)$, we follow the procedure used in Longstaff, Mithal, and Neis (2005) to estimate the relation between debt maturities and the non-default components in corporate bond spreads, which are approximately the same as the bond-CDS spreads. The bond price data is from the Mergent Fixed Income Securities Database (FISD); the CDS data is from Markit. Our sample period is from 2004 to 2010. To address the possible selection bias that firms facing higher long-term non-default spreads will tend to issue shorter term bonds, we follow Helwege and Turner (1999) by restricting the sample to firms that issue both short-term (maturity less than 3 years) and long-term bonds (maturity longer than 7 years). More details of the procedure are in Appendix B.

We then regress the non-default corporate bond spread on bond maturity, controlling for other bond (bond age, issuing amount, and coupon rate) and firm characteristics (systematic beta, size, book leverage, market-to-book ratio, and profit volatility). The results are presented in Table A.1. In the sub-sample excluding the financial crisis (July 2007 to December 2009), we find that increasing the maturity by 1 year raises the non-default spread of corporate bonds by 1.4 bps on average. During the crisis, the coefficient rises to 17.5 bps. Consistent with the regression estimates, our calibrated non-default spreads for a 3-year bond and a 8-year bond in state $G$ are 0.3 bps and 5 bps, respectively. Since state $B$ in our model represents a typical recession rather than a financial crisis, we calibrate the non-default spread in state $B$ to match half the effect observed in the crisis, with the spreads for a 3 -year bond and a 8-year bond rising to 13 bps and 45 bps, respectively. 


\subsection{Maturity Choice}

The model implications for the benchmark firm are summarized in Panel B of Table 1. We assume that the firm makes its optimal capital structure decision in state $G$. The initial interest coverage $\left(y_{0} / C\right)$ is 2.6. The initial market leverage is $29.2 \%$ in state $G$. Fixing the level of cash flow, the same amount of debt will imply a market leverage of $32.4 \%$ in state $B$ due to the fact that equity value drops more than debt value in recessions. The optimally chosen maturity for state $G$ is 5.5 years, and it drops to 5.0 years for state $B$. Based on the interpretation of maturity adjustment in equation (6), $m_{B}=1 / 5$ corresponds to $\bar{m}_{B}=0.31$. That means the firm replaces its 5-year debt that retires in state $B$ with new 3.3-year debt. The decline in maturity in state $B$ is the direct result of the higher non-default spread in that state. If we were to hold the non-default spread constant across the two states, the firm will actually prefer longer debt maturity in state $B$ due to higher default risk.

The model-implied 10-year default probability is $4.6 \%$ in state $G$ and $6.0 \%$ in state $B$, while the the 10-year credit spread is 102.6 bps in state $G$ (based on initial leverage) and 141.1 bps in state $B$. These values closely match the historical average default rate and credit spread for Baa-rated firms. Finally, the conditional equity Sharpe ratio is 0.12 in state $G$ and 0.22 in state $B$.

When computing the credit spreads at different maturities, we focus on the default-related component. To do so, we take the firm's optimal default policy as given and simulate under the risk-neutral probability the cash flows for a fictitious bond (with a given maturity) that defaults at the same time as the firm. The bond recovery rate is assumed to be $44 \%$ in state $G$ and $20 \%$ in state $B$, which matches the historical average recovery rate of $41.4 \%$. We then price the cash flows without adding the non-default spread to the riskfree rate.

Next, to study how systematic risk affects firms' maturity structure, we compute the optimal debt maturity for firms with different amount of systematic volatility in cash flows, which are obtained by rescaling the systematic volatility of cash flows $\left(\sigma_{\Lambda}(G), \sigma_{\Lambda}(B)\right)$ for the benchmark firm while keeping the idiosyncratic volatility of cash flows $\sigma_{f}$ unchanged. ${ }^{7}$ We

\footnotetext{
${ }^{7}$ We get similar results if we rescale the systematic volatilities while holding the average total volatility of cash flows fixed.
} 

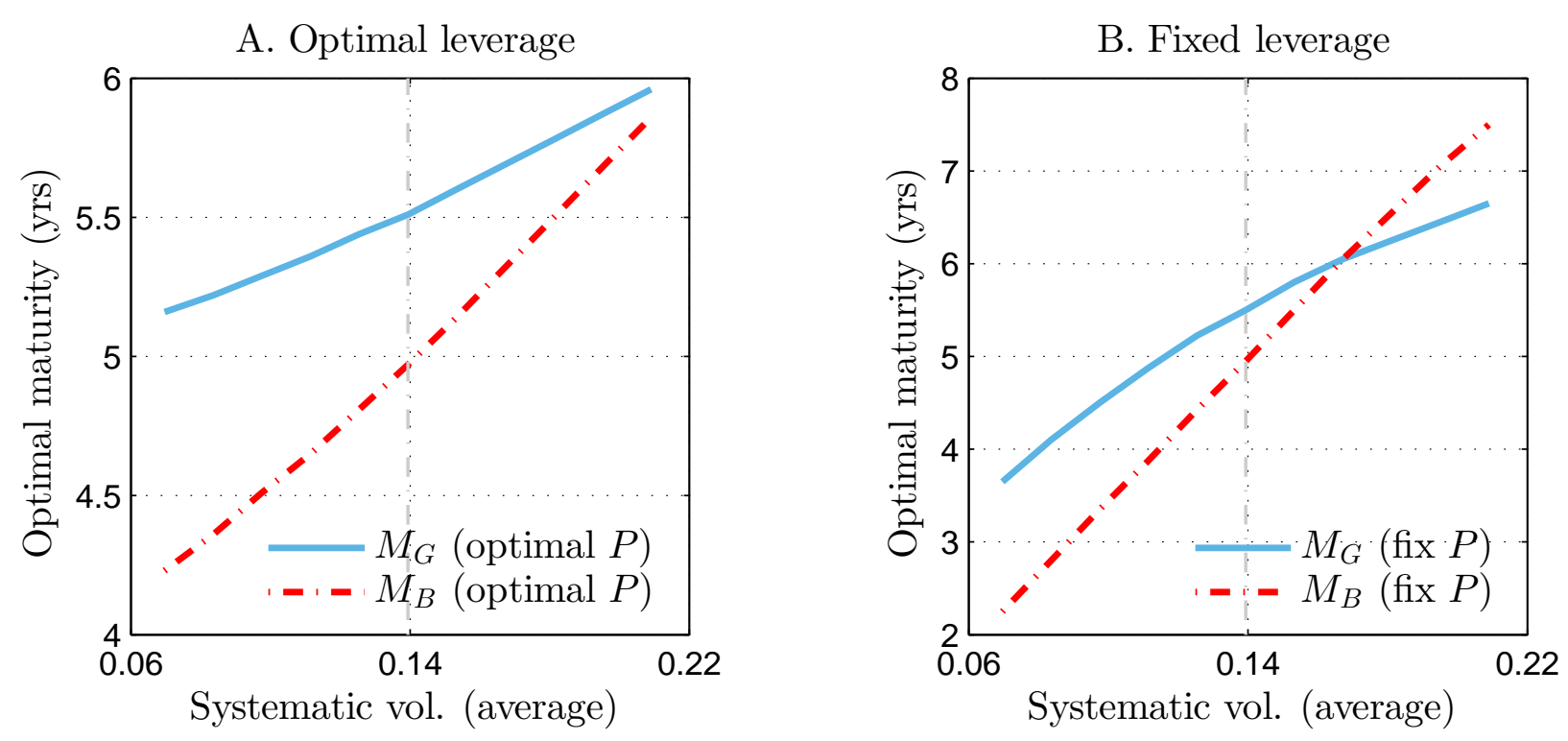

Figure 3: Optimal debt maturity. In Panel A, we hold fixed the idiosyncratic volatility of cash flow while letting the systematic volatility vary and then plot the resulting choices of the optimal average maturity in the two states under optimal leverage. In Panel B, we repeat the exercise but hold leverage fixed at the level of the benchmark firm. The benchmark firm has an average systematic volatility of 0.139 .

first examine the case where leverage is chosen optimally for each firm, and then the case where leverage is held constant across firms.

Figure 3 shows the results. In Panel A, controlling for the idiosyncratic cash-flow volatility, optimal debt maturity in both the expansion and recession state increases for firms with higher systematic volatility. For example, as the average systematic volatility rises from 0.07 to 0.21 , the optimal maturity in state $G$ rises from 5.2 to 6.0 years, whereas the maturity in state $B$ rises from 4.2 to 5.9 years. The result is consistent with the intuition that firms with high systematic risk face higher rollover risk and will prefer longer debt maturity, despite the higher liquidity costs associated with longer maturity debt. While the exact size of the effect of systematic volatility on debt maturity depends on the calibration of the non-default spread, the qualitative result is robust because the non-default spread in the model is unaffected by firms' systematic volatilities.

The graph also shows that, for the same firm, the optimal debt maturity is lower in state 
$B$, and that the increase in debt maturity with systematic volatility is faster in a recession than in an expansion. As a result, the debt maturity for firms with high systematic risk changes very little over the business cycle, while that for firms with low systematic risk changes much more. These two results are more sensitive to the calibration of the non-default spreads. They will hold if the non-default spread is close to being linearly increasing in maturity and the sensitivity of the non-default spread to maturity rises sufficiently in state $B$, which we explain later.

In Panel B of Figure 3, instead of allowing firms with different systematic risk to choose their leverage optimally, we fix the leverage for all firms at the same level as the benchmark firm, which has an average systematic volatility of $13.8 \%$. While the results are qualitatively similar, debt maturity in this case increases faster with systematic volatility in both states $G$ and $B$. For firms with sufficiently high systematic risk exposures, the debt maturity in state $B$ can become even higher than the maturity in state $G$, indicating that these firms roll their maturing debt into longer maturity in recessions.

Why does the optimal debt maturity become more sensitive to systematic volatility after controlling for leverage? Because of higher expected costs of financial distress, firms with high systematic risk exposures will optimally choose lower leverage. By fixing their leverage at the level of the benchmark firm, firms with high systematic volatility end up with higher leverage than the optimal amount. As a result, using long-term debt to reduce rollover risk becomes more important for these firms, especially in bad times.

While an analytical characterization of the optimal maturity choice is not possible in our model, we use Figure 4 to provide more intuition on how maturity choice is affected by systematic risk. The marginal costs of picking longer maturity are the marginal costs of illiquidity, which is positive because the non-default spread $\ell(m, s)$ is increasing with debt maturity. The marginal benefits of longer maturity are the marginal savings on default costs, which is also positive because default probability falls with longer maturity. Intuitively, a firm finds its optimal debt maturity by equating the marginal costs and benefits.

Now let's consider the problem in state $G$. On the one hand, the marginal costs of 


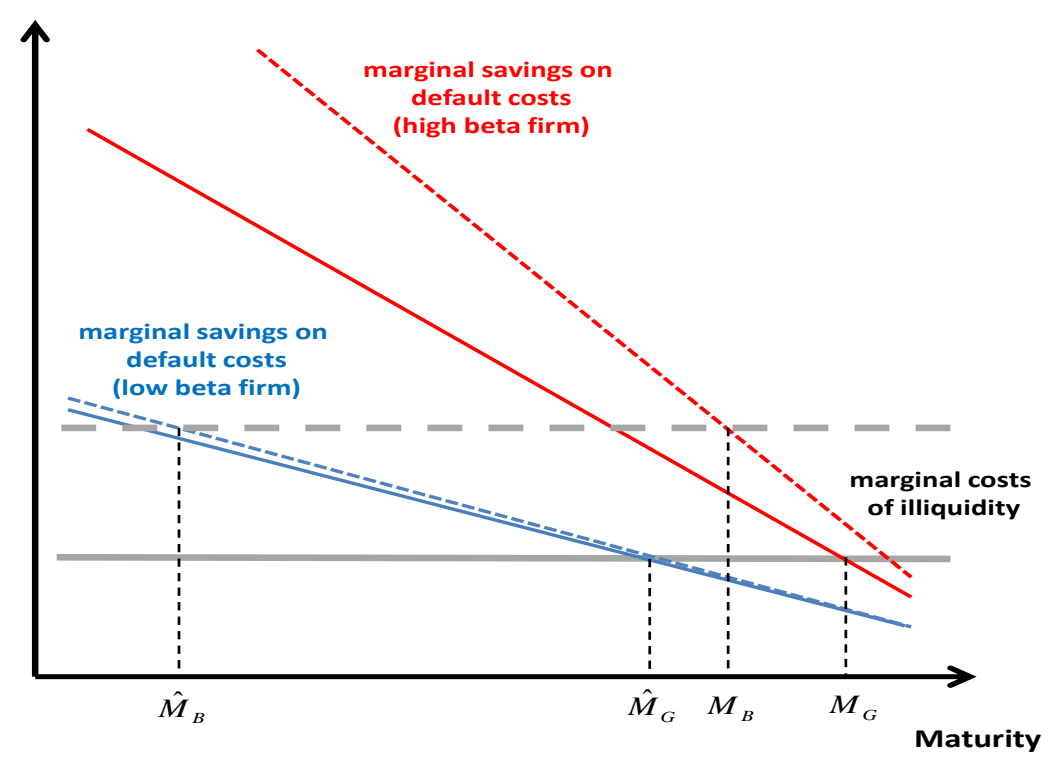

Figure 4: The optimal debt maturity. The solid grey line plots the marginal costs of illiquidity when increasing the maturity in state $G$. The solid blue and red lines plot a low-beta firm and a high-beta firm's marginal savings on default costs when increasing the maturity in state $G$. Their dash-line counterparts show the marginal costs and benefits in state $B . \widehat{M}_{s}$ and $M_{s}$ are the optimal maturities for the low-beta and high-beta firm.

illiquidity according to our calibration are approximately constant within the range of reasonable maturities (despite the nonlinear specification for $\ell(m, s)$ ). On the other hand, the marginal savings on default costs decline with maturity. Compared to a low-beta firm, the marginal savings on default costs for a high-beta firm not only are higher, but also decline faster with maturity, all else equal. As the graph shows, this results in the high-beta firm choosing a longer debt maturity $\left(M_{G}\right)$ than the low-beta firms $\left(\widehat{M}_{G}\right)$ in state $G{ }^{8}$

Next, when the economy moves into state $B$, higher risk premium in that state significantly raises the marginal savings on default costs for the high-beta firm, but only has a small effect on the low-beta firm. If the marginal costs of illiquidity remain the same as in state $G$, then both firms will increase their debt maturity in order to reduce default risk, especially the high-beta firm. As the marginal costs of illiquidity rise in state $B$, they start to offset the firms' incentive to increase debt maturity. As Figure 4 shows, a sufficient increase in

\footnotetext{
${ }^{8}$ For this result to hold, it is sufficient to have the marginal costs of illiquidity being non-decreasing in maturity, and the marginal savings on default costs being increasing with beta.
} 
the marginal costs of illiquidity from $G$ to $B$ will lead firms to reduce their debt maturity. This reduction in maturity will be larger for the low-beta firm. As a result, firms' maturity choices in state $B$ become more sensitive to their systematic risk exposures. Notice that this last result can change if the marginal costs of illiquidity are no longer constant in maturity. Intuitively, if the non-default spread becomes highly nonlinear in maturity, it could lead to a larger reduction in the maturity of the high-beta firm.

\subsection{Maturity and Credit Risk}

What are the implications of the maturity dynamics for the term structure of credit spreads? ${ }^{9}$ In this section, we examine the following questions about debt maturity and credit risk.

1. How much does the pro-cyclical variation in debt maturity amplify the fluctuations in credit spreads over the business cycle?

2. How does the endogenous maturity choice affect the cross-sectional relation between debt maturity and rollover risk?

3. How does a lumpy maturity structure affect the term structure of credit spreads differently from a granular maturity structure?

To answer the first question, we conduct the following comparative static exercise. Consider the benchmark firm from Section 3.2. It optimally chooses an initial leverage of $29.2 \%$ (with interest coverage of 2.6) and debt maturity of 5.5 years in state $G$, but drops the maturity to 5.0 years (on average) in state $B$. To measure the effect of this maturity reduction in state $B$ on credit risk, we compute the differences in the credit spreads between the benchmark firm and a firm whose debt maturity is exogenously fixed at 5.5 years in both states (which requires solving for a different default policy).

Panel A of Figure 5 shows the results. When debt maturity is reduced in state $B$, credit spreads go up in both states $G$ and $B$, but more in state $B$. This suggests that pro-cyclical debt maturity will indeed make the credit spreads more volatile over the business cycle.

\footnotetext{
${ }^{9}$ All the credit spreads reported in this section refer to the default component of the credit spreads.
} 

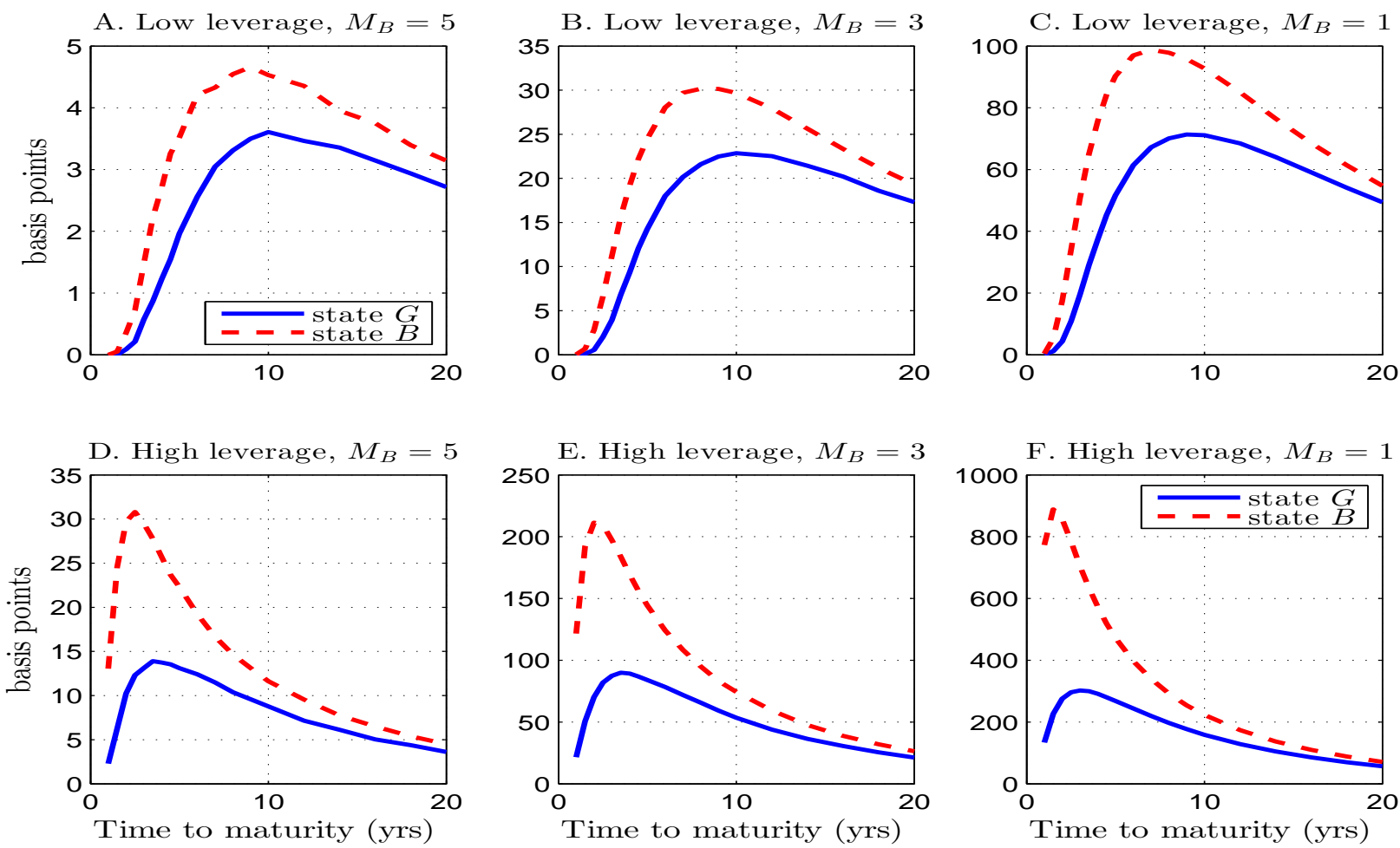

Figure 5: The amplification effect of maturity choice on credit spreads. This figure plots the differences in credit spreads between a firm with constant debt maturity of 5.5 years in states $G$ and $B$ and a firm that has maturity of 5.5 years in state $G$ but shorter maturity in state $B$. The values for debt maturity in state $B$ are: 5 years (the optimal choice for the benchmark firm), 3 years, and 1 year. In Panels A-C, the firm's leverage is at the optimal level, with interest coverage of 2.6. In Panels D-F, the firm's interest coverage is fixed at 1.3.

However, quantitatively, the effect of maturity reduction on credit spreads is very small (less than $5 \mathrm{bps}$ ). This is not surprising given the benchmark firm's moderate leverage and the relatively small change in maturity between states $G$ and $B$.

What could make the debt maturity drop more in state $B$ ? Revisiting the mechanics for how debt maturity is adjusted in Section 2.2, we see that debt maturity will become shorter in state $B$ if the firm rolls the retired debt into new debt with shorter maturity (due to higher non-default spread for longer-term debt), or if the bad state is more persistent. Large maturity reductions can also happen if the maturity structure is lumpy, which we explore later. For illustration, consider the cases where the average debt maturity falls from 5.5 years to 3 years and 1 year in state $B$, respectively. Based on the interpretation of maturity 
adjustment in equation (6), $m_{B}=1 / 3$ corresponds to $\bar{m}_{B}=1.2$, meaning the retired bonds are rolled into new bonds with maturity of 10 months, while $m_{B}=1$ corresponds to $\bar{m}_{B}=5.7$ or approximately a maturity of 2 months.

As Panel B and C of Figure 5 show, the effects on credit spreads increase in a nonlinear fashion as the reduction in debt maturity becomes larger. When the average maturity in state $B$ drops to 3 years, credit spreads rise by up to 23 bps in state $G$ and 30 bps in state $B$. If the average maturity in state $B$ drops to 1 year, credit spreads can rise by up to 71 bps in state $G$ and 99 bps in state $B$.

Next, in Panels D, E, and F, we repeat the exercises above after raising the initial leverage of the benchmark firm (with the interest coverage dropping from 2.6 to 1.3). The cases of high leverage are relevant because even though firms start with optimal low leverage, their leverage can rise substantially over time due to negative cash-flow shocks and the costs associated with downward adjustment in the debt structure. Since we assume firms precommit to their choices of $\left(m_{G}, m_{B}\right)$, we are looking at the effects of the same change in debt maturity as in Panels A-C after the firm's leverage has risen.

Not surprisingly, the maturity effect on credit spreads becomes stronger as leverage increases. Even when the maturity only drops from 5.5 years to 5.0 years, the credit spread can rise by up to $13 \mathrm{bps}$ in state $G$ and $31 \mathrm{bps}$ in state $B$. The nonlinearity of the maturity effect is even more visible in this case. When the average maturity in state $B$ drops to 1 year, credit spreads can rise by up to 300 bps in state $G$ and 890 bps in state $B$. More interestingly, the largest increases in credit spreads due to the maturity reduction are now concentrated at the short end of the credit spread curve (1-3 years) instead of the middle part (7-10 years) in the case of low leverage.

The intuition is the following. With low leverage, the firm faces low default risk. In this case, especially in the near future, newly issued debt will be priced close to par value, and more frequent rollover (even when $m_{B}=1$ ) will not raise the burden for equity holders (see (11)). This is why the increase in credit spreads is negligible at the short end of the credit spread curve. Due to the volatility of cash flows, financial distress becomes more likely with 

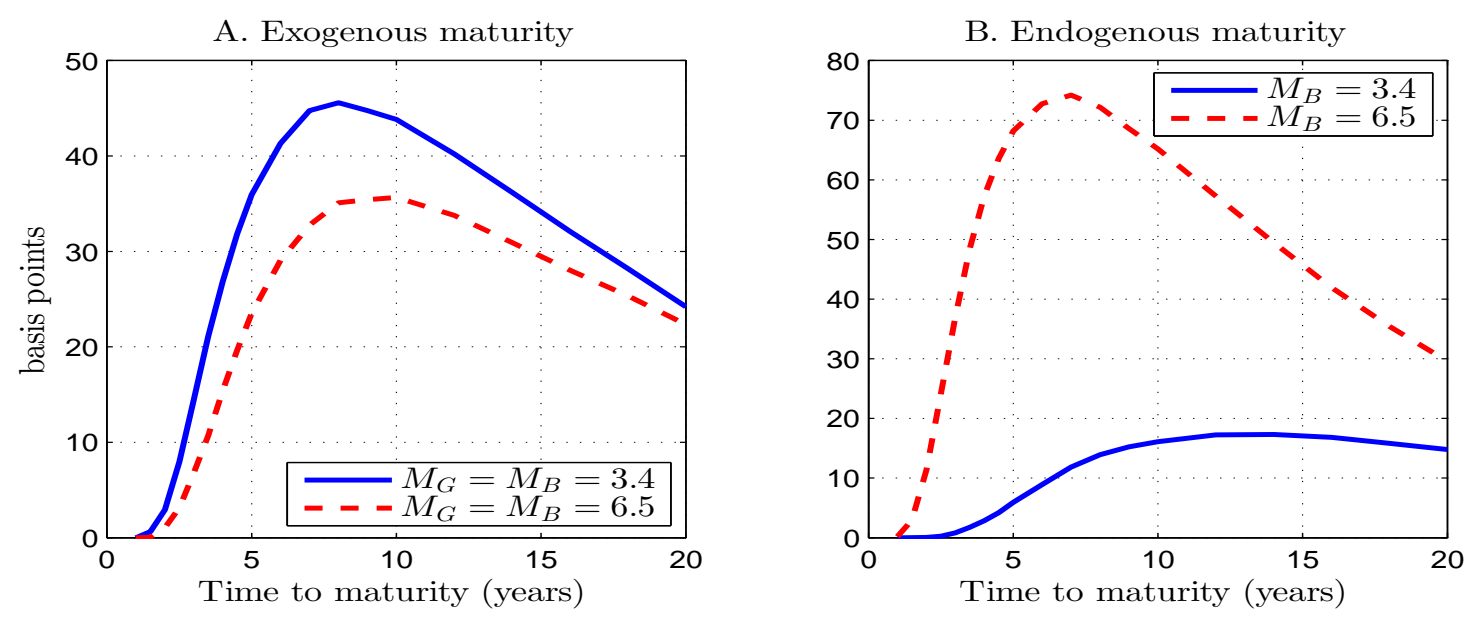

Figure 6: Credit spread changes under exogenous vs. endogenous maturity choice. This figure plots the increase in credit spreads when the aggregate state switches from $G$ to $B$ for different firms. In Panel A, the two firms have the same systematic risk exposures but are given different debt maturity choice exogenously. In Panel $\mathrm{B}$, the two firms endogenously choose different maturity structure due to differences in systematic risk.

the passage of time, and the maturity effect becomes stronger. At even longer horizons, the firm's cash flows are expected to grow and the maturity will lengthen once the economy leaves the bad state, both of which cause the maturity effect to dissipate. In contrast, the impact of shorter maturity on default risk immediately shows up in the case of high leverage, because the newly issued bonds are priced under par already.

Next, we investigate how endogenous maturity choice affects the rollover risk. The standard notion of rollover risk suggests that shorter maturity leads to stronger reaction of credit spreads to aggregate shocks. This may no longer be true when maturity choice is endogenous. As our model shows, firms with longer maturity tend to have higher beta, especially in bad times. The fact that high-beta firms are fundamentally more exposed to aggregate shocks could offset and even reverse the effects of rollover risk.

We illustrate this point in Figure 6. In Panel A, we take two firms with identical asset beta (the same as the benchmark firm), but fix their debt maturity exogenously at 6.5 years and 3.4 years, respectively. Notice that we not only ignore the endogeneity of maturity choice in this case, but also do not allow the maturity to change across the states. In Panel B, we 
identify two firms with different systematic volatility (but the same average total volatility), which leads them to choose different debt maturities endogenously. One firm has an average systematic volatility of $18.9 \%$ and sets its debt maturity in state $B$ optimally at 6.5 years. The other has an average systematic volatility of $8.9 \%$ and sets its maturity in state $B$ at 3.4 years. The leverage for all the firms are fixed at the same level as the benchmark firm. The figure plots the change in credit spreads from state $G$ to $B$ for different horizons, which measures the response of the credit spreads to the aggregate shock.

Panel A shows that, with exogenous maturity, the credit spread rises more for the firm with shorter maturity, which is consistent with the standard intuition of rollover risk. In Panel B, however, the firm with longer maturity actually has a bigger increase in credit spreads than the one with shorter maturity because of its larger exposure to systematic risk.

The third question we study is the effect of lumpiness of maturity structure. How would the maturity effect change if the firm issues debt with the same maturity as before, but has all the debt retiring in a short period of time rather than at a constant rate? We use the lumpy maturity model developed in Section 2.3 to study this question. Specifically, we assume that the benchmark firm picks the same maturity of $T_{G}=5.5$ years in state $G$. However, instead of having debt retired at the rate of $m_{G}=1 / 5.5$, we assume that all the debt will (in expectation) retire in their last year to maturity. In addition, we assume that the firm is forced to roll over maturing debt into one-year debt in state $B$. These maturity dynamics are approximated by the 4-state model. We again consider two levels of financial leverage, one with initial interest coverage of 2.6 (the same as the benchmark firm), the other with interest coverage of 1.3 (high leverage).

Figure 7 reports the results. The left panels are based on the results for the low-leverage firm (with the same interest coverage of 2.6 as the the benchmark firm). Panel A shows the full term structure of credit spreads. The term structure is mostly upward sloping. Controlling for maturity, credit spreads are the highest in state $B_{m=1}$, where the aggregate economic conditions are bad and a large amount of debt is due, and lowest in state $G_{m=0}$, where the aggregate economic conditions are good and no debt is due. 
A. Term structure: low leverage
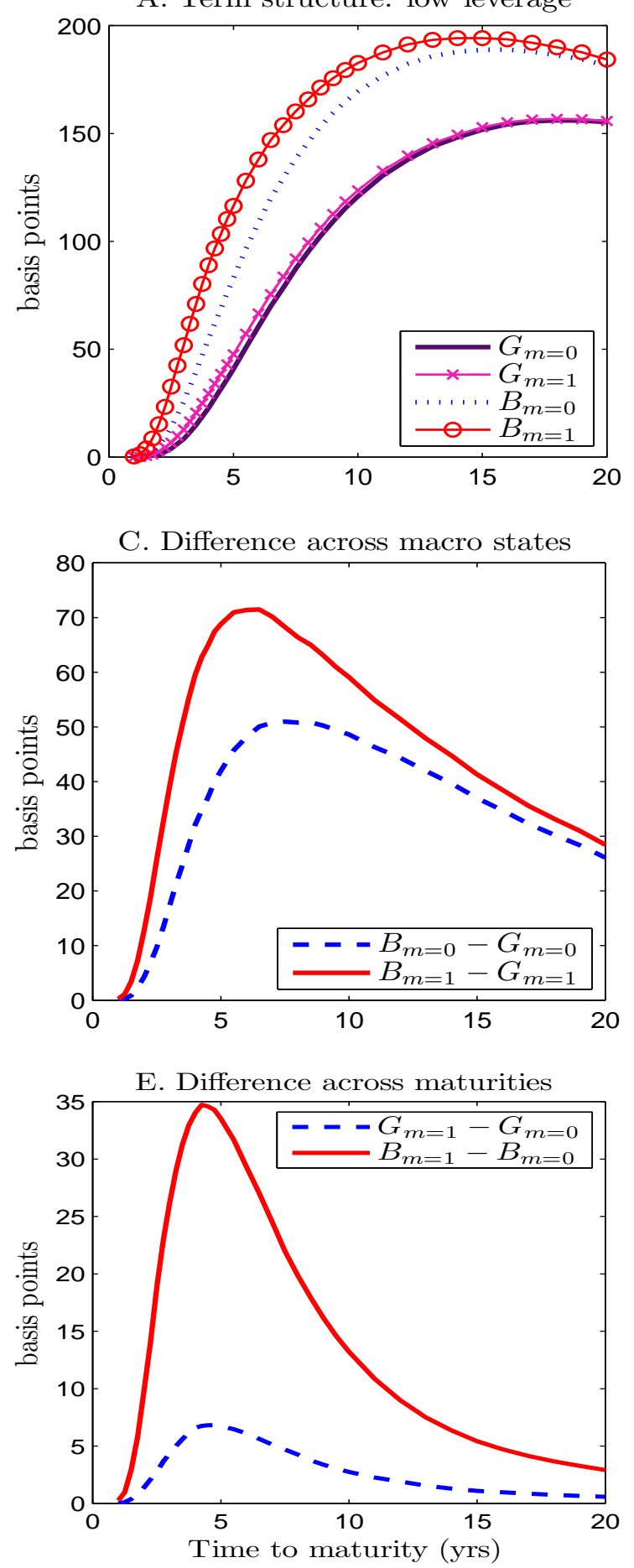

B. Term structure: high leverage
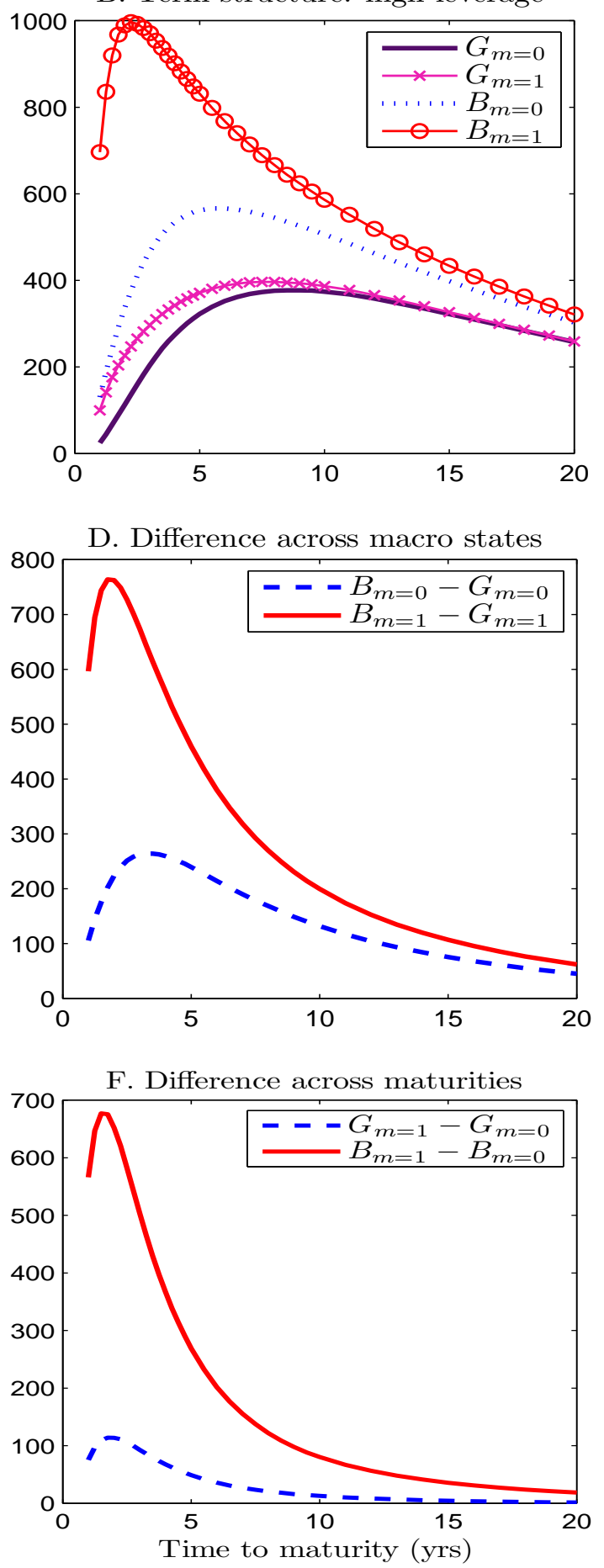

Figure 7: Credit spreads for a lumpy maturity structure. This figure plots the term structure of credit spreads in the model of lumpy maturity structure. The left columns (Panels A, $\mathrm{C}, \mathrm{E}$ ) are for a low-leverage firm (with interest coverage of 2.6). The right columns (Panels B, D, F) are for a high-leverage firm (with interest coverage of 1.3). 
For the low-leverage firm, a larger part of the differences in the credit spreads across the 4 states are due to differences in the macroeconomic conditions instead of the maturity states. To see this, compare Panel C, which plots the differences in credit spreads across the two aggregate states (holding the maturity state fixed), and Panel E, which plots the differences in credit spreads across the two maturity states (holding the aggregate state fixed). Credit spreads rise by up to 51 bps if the aggregate state changes at a time when no debt is due immediately, and by up to 71 bps when the aggregate state changes just as a large amount of debt is coming due. Next, conditional on being in state $G$, whether there is a large amount of debt due soon or not has very little impact on the credit spreads (up to 7 bps), but the difference becomes more significant in state $B$ (up to $35 \mathrm{bps).} \mathrm{The} \mathrm{biggest} \mathrm{increases} \mathrm{in} \mathrm{credit}$ spread are at 5-8 year maturity. For maturity of 2 years or less, neither a change in the aggregate state nor the maturity state has any sizable impact on the credit spreads.

The magnitude of the effect that a lumpy maturity structure has on the credit spreads of a high leverage firm is quite striking. The firm's credit spreads rise more following a bad aggregate shock, especially when the aggregate shock arrives when a large amount of debt is due. In Panel D, the rise in credit spreads can be as high as 260 bps when no debt is due immediately, vs. 760 bps when a large amount of debt is due soon. In Panel F, credit spreads can rise by up to 110 bps in state $G$ and up to 680 bps in state $B$ due to the fact that a large amount of debt needs to be rolled over soon. The biggest increases in credit spread are now at 1-3 year maturity, and the effects weaken quite rapidly with longer maturity.

Finally, in unreported results, we compute the credit spreads for two firms with different asset betas (0.5 and 1.2) but the same leverage as the benchmark firm (with interest coverage of 2.6). We find that the lumpy maturity structure itself has essentially no impact on the credit spreads for the low-beta firm. For the high-beta firm, the differences in the credit spreads between the state with a large amount of debt retiring and the state with no debt retiring can be up to 12 bps in state $G$ and up to 70 bps in state $B$, which doubles the size of the effect for the benchmark firm as reported in Panel E of Figure 7.

In summary, our model analysis establishes the following new predictions about the relations between firms' systematic risk, debt maturity, and credit risk: 
1. Controlling for either total or idiosyncratic volatility, firms with higher systematic risk exposures will have longer debt maturity.

2. Controlling for leverage, debt maturity will become more sensitive to firms' systematic risk exposures.

3. The sensitivity of debt maturity to systematic risk exposure rises in recessions and other times of high risk premium.

4. Maturity reduction amplifies the impact of aggregate shocks on the credit spreads. This amplification effect is stronger for firms with higher leverage or high systematic risk, especially at the short end of the credit spread curve.

\section{Empirical Evidence}

In this section, we test the model implications about debt maturity and credit spreads in the cross section of firms and in the time series.

\subsection{Data}

We merge the data from COMPUSTAT annual industrial files and the Center for Research in Securities Prices (CRSP) files for the period 1974 to $2010 .{ }^{10}$ We exclude financial firms (SIC codes 6000-6999), utilities (SIC codes 4900-4999), and quasi-public firms (SIC codes greater than 8999), whose capital structure decisions can be subject to regulation. In addition, we require firms in our sample to have total debt that represents at least $5 \%$ of their assets. ${ }^{11}$ All the variables are winsorized at the $1 \%$ and $99 \%$ level. Finally, we remove firm-year observations with extreme year-to-year changes in the capital structure, defined as having changes in book leverage or long-term debt share in the lowest or highest $1 \%$, which are likely due to major corporate events such as mergers, acquisitions, and spin-offs.

\footnotetext{
${ }^{10} 1974$ is the first year in which COMPUSTAT begins to report balance sheet information used to construct our proxies for debt maturity.

${ }^{11}$ Choosing a different threshold of $3 \%$ generates very similar results.
} 
Following previous studies of debt maturity (see Barclay and Smith (1995), Guedes and Opler (1996), and Stohs and Mauer (1996)), we construct the benchmark measure of debt maturity using the long-term debt share, which is the percentage of total debt that are due in more than 3 years (ldebt3y). For robustness, we also measure long-term debt share using the percentage of total debt due in more than $n$ years (ldebtny), with $n=1,2,4,5$. For each firm, COMPUSTAT provides information on the amount of debt in 6 maturity categories: debt due in less than 1 year $(d l c)$, in years two to five $(d d 2, d d 3, d d 4$, and $d d 5)$, and in more than 5 years, which allows us to construct the above measures of debt maturity. In addition to the long-term debt share, we also construct a book-value weighted numerical estimate of debt maturity (debtmat) by assuming that the average maturities of the 6 COMPUSTAT maturity categories are 0.5 year, 1.5 years, 2.5 years, 3.5 years, 4.5 years, and 10 years.

Our primary measure of firms' exposure to systematic risk is the asset market beta. Since firm asset values are not directly observable, we follow Bharath and Shumway (2008) and back out asset betas from equity betas based on the Merton (1974) model. Equity betas are computed using past 36 months of equity returns and value-weighted market returns ${ }^{12}$. In this process, we also obtain the Merton distance-to-default measure (mertondd), which is a proxy for firms' default probability, the total asset volatility (assetvol), as well as the systematic and idiosyncratic asset volatilities (sys assetvol and id assetvol). Moreover, following Acharya, Almeida, and Campello (2012), we compute the "asset bank beta," which is based on a firm's exposure to a banking sector portfolio, and the "asset tail beta," which captures a firm's exposure to large negative shocks to the market portfolio.

The various asset betas constructed above could be mechanically related to firms' leverage, which might affect firms' maturity choices. We address this concern with two additional measures of systematic risk exposure. First, we compute firms' cash flow betas using rolling 20-year windows. The cash flow beta is defined as the covariance between firm-level and aggregate cash flow changes (normalized by total assets from the previous year) divided by the variance of aggregate cash flow changes. Second, Gomes, Kogan, and Yogo (2009) show that demand for durable goods is more cyclical than for nondurable goods and services. Thus,

\footnotetext{
${ }^{12}$ Computing equity betas with past 12 or 24 months of equity returns generates similar results.
} 
durable-good producers are exposed to higher systematic risk than non-durables and service producers. They classify industries into three groups according to the durability of a firm's output. We use their classifications as one more measure of systematic risk exposure.

Previous empirical studies find that debt maturity decisions are related to several firm characteristics, including firm size (log market assets, or mkat), abnormal earnings (abnearn), ${ }^{13}$ book leverage (bklev), market-to-book ratio $(m k 2 b k)$, asset maturity (assetmat), and profit volatility (profitvol). We control for these firm characteristics in our main regressions.

Table 2 provides the summary statistics for the variables used in our paper. The median firm has $85 \%$ of their debt due in more than 1 year, $58 \%$ of the debt due in more than 3 years, and $32 \%$ due in more than 5 years. There is also considerable cross-sectional variation in all three measures. The standard deviation of ldebt3y (the percentage of debt due in more than 3 years) is $32 \%$, and the interquartile range of ldebt3y is from $27 \%$ to $79 \%$. Based on our numerical measure of debt maturity, the median debt maturity is 4.7 years, while the interquartile range is from 2.5 years to 6.8 years. The median firm in our sample has book leverage of about $27 \%$. The median asset beta is 0.80 , whereas the median equity beta is 1.07. The median systematic and idiosyncratic asset volatilities are $12 \%$ and $30 \%$, respectively. The correlations among the different risk measures are reported in Panel B of Table 2. The various beta proxies are positively correlated. They are also positively correlated with asset volatility. As expected, the Merton's distance-to-default measure is negatively correlated with asset volatility. But its correlation with asset beta is much smaller (or even positive), probably reflecting the fact that high beta firms choose low leverage to reduce default probability.

\subsection{Debt Maturity}

\subsubsection{Cross section of debt maturity}

As a first look at the model's prediction on the relation between debt maturity and firms' systematic risk exposures, we use the Fama-MacBeth procedure and regress the long-term

\footnotetext{
${ }^{13}$ Following Barclay and Smith (1995), we define "abnormal earnings" as the change in earnings from year $t$ to $t+1$ normalized by market equity at the end of year $t$.
} 
A. F-M coefficient for systematic asset vol

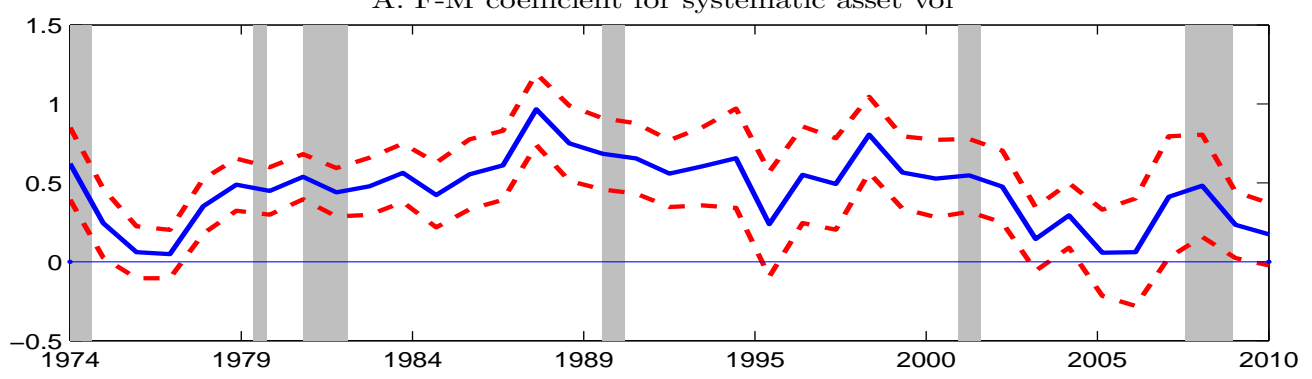

B. F-M coefficient for idiosyncratic asset vol

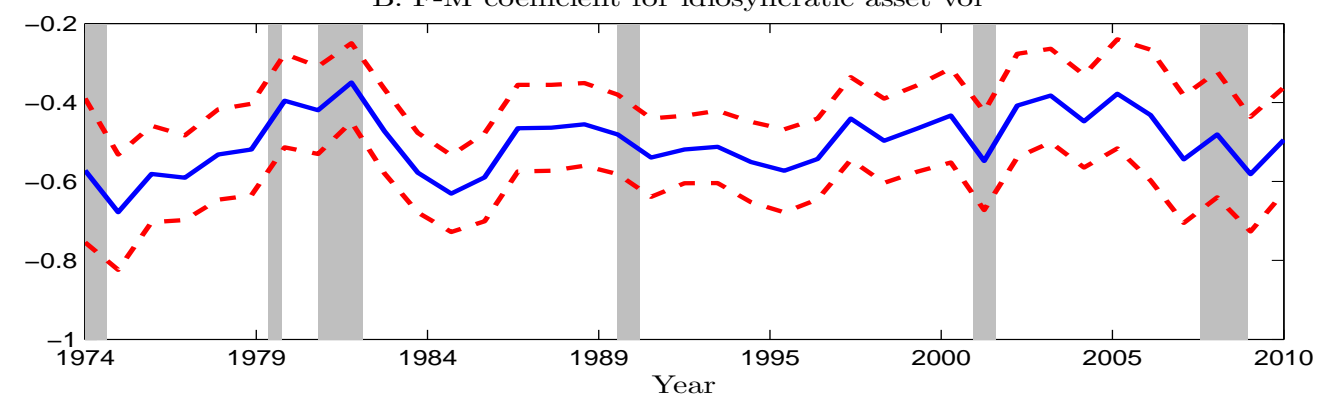

Figure 8: Time series of Fama-MacBeth coefficients for systematic and idiosyncratic volatility. This graph plots time series of coefficient estimates in a cross-sectional regression of long-term debt shares on systematic and idiosyncratic asset volatility. The confidence intervals are at $95 \%$ level. The shaded areas denote NBER-dated recessions.

debt share on the systematic and idiosyncratic asset volatility, controlling for book leverage. Figure 8 plots the time series of the coefficients on the systematic and idiosyncratic volatilities and their $95 \%$ confidence intervals, which are computed using heteroscedasticity consistent standard errors.

The estimated coefficient for the systematic asset volatility in Panel A is significantly positive for the majority of the sample years, and significantly positive for the overall sample. The average estimated coefficient of the systematic volatility is 0.45 . Economically, this estimate implies that moving from the 10th to the 90th percentile for the systematic asset volatility in our sample increases the fraction of long-term debt by $10.4 \%$. These results support the model's prediction that, on average, firms with larger exposure to systematic risk have more long-term debt. In contrast, Panel B shows that the coefficient on the idiosyncratic asset volatility is significantly negative throughout the sample, implying that firms with high idiosyncratic risk have shorter maturity. 
Earlier studies by Barclay and Smith (1995) and Stohs and Mauer (1996)) have documented a negative relation between debt maturity and measures of firm volatility (such as the volatility of asset returns and earnings changes). Our results suggest that this negative relation is driven by the negative relation between debt maturity and idiosyncratic volatility, which is consistent with the theory of debt maturity based on information asymmetries. As Flannery (1986) and Diamond (1991) point out, issuing short-term debt can be a credible signal for firm quality. Since the problem of asymmetric information is more naturally associated with firm-specific uncertainty (managers are unlikely to have more information about the market than outside investors), firms with higher idiosyncratic risk will be treated as having worse quality when issuing long-term bonds, which leads them to choose shorter maturity.

In the following analysis, we investigate these patterns in more detail. We first run cross-sectional regressions with the following general specification:

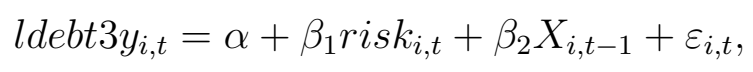

where ldebt3y, the share of long-term debt with maturities of 3 years or more, is the proxy for debt maturity; risk $_{i, t}$ represents various measures of firms' systematic risk exposures; $X_{i, t}$ represents firm-specific controls, including total asset volatility (assetvol), market assets (mkat), abnormal earnings (abnearn), book leverage (bklev), market-to-book ratio ( $m k 2 b k)$, asset maturity (assetmat), and profit volatility (profitvol).

The regression results are presented in columns (1) - (8) of Table 3. We compute robust t-statistics using Newey and West (1987) standard errors with 2 lags, except in the case of cash flow beta, where we use 10 lags. Column (9) reports the cross-sectional regression of long-term debt shares on the durability measure suggested by Gomes, Kogan, and Yogo (2009). This measure is fixed over time, so we regress each firm's average long-term debt share on the durability measure and averages of other firm controls.

The coefficient of the asset market beta in column (1) is positive but insignificant in the univariate regression. After controlling for asset volatility, asset market beta becomes significantly positively correlated with debt maturity (column (2)). The coefficient estimate 
of 0.084 implies that a one-standard deviation increase in asset beta, keeping total asset volatility constant, is associated with a $5.4 \%$ increase in the long-term debt share. Consistent with our model prediction, the effect of asset beta on debt maturity further strengthens to 0.103 after controlling for book leverage (column (3)), implying that a one-standard deviation increase in asset beta raises the long-term debt share by $6.5 \%$. The coefficient estimate on asset volatility is negative and statistically significant, which is consistent with Barclay and Smith (1995), Guedes and Opler (1996), and Stohs and Mauer (1996).

In the cross section, holding asset beta fixed while changing total asset volatility is equivalent to holding systematic volatility fixed while increasing idiosyncratic volatility. Thus, the negative effect of asset volatility on debt maturity is driven by the negative relation between idiosyncratic volatility and maturity as shown in column (4). It is also intuitive that controlling for asset volatility is key to finding a significant effect for asset beta. Firms with high asset beta will tend to have higher idiosyncratic volatility, which offsets the effect of systematic volatility on debt maturity.

In column (5), we introduce other firm controls into the regression. The coefficient estimate of the asset market beta is 0.048 , smaller than the previous specifications but still highly significant. The smaller coefficient could be due to the fact that firm characteristics such as size and book-to-market ratio are also related to systematic risk. The coefficient on asset volatility becomes much smaller than before, which is because firm controls such as size and profit volatility are highly correlated with idiosyncratic asset volatility.

Columns (6) - (8) report regression results when we replace asset market beta with asset bank beta, asset tail beta, and cash flow beta, respectively. The coefficient estimates of asset bank beta, asset tail beta, and cash flow beta are 0.051, 0.042, and 0.008, respectively. These estimates imply that a one-standard deviation increase in a firm's corresponding beta measure lengthens its long-term debt share by $2.3 \%, 2.5 \%$, and $2.1 \%$.

Column (9) reports the cross-sectional regression results when we use the industry classification for producers of durable goods, nondurable goods, and services as proxy for systematic risk exposure. The results show that the long-term debt share of durable good 
producers, which have more cyclical cash flows, is $2.0 \%$ larger than that of non-durable good producers, and $3.4 \%$ larger than that of service producers.

Table 4 reports the results for pooled regressions, where we add year dummies to absorb time-specific effects, and industry dummies (3-digit SIC code) to control for industry fixedeffects. We compute the standard errors by clustering the observations at the industry level. ${ }^{14}$ The results for the pooled regressions are quantitatively similar to the Fama-MacBeth regressions and are in support of the model prediction that debt maturity is increasing in firms' systematic risk exposures.

Besides systematic risk measures, the effects of various other firm characteristics on maturity are consistent with earlier studies. Everything else equal, firms with low total asset volatility, large size, high leverage, low market-to-book ratio, long asset maturity, and low profit volatility are more likely to have longer debt maturity.

\subsubsection{Impact of macroeconomic conditions}

Having examined the cross-sectional relation between systematic risk and debt maturity, we now test the model's time-series prediction on systematic risk and debt maturity.

As a proxy for macroeconomic conditions, we obtain recession/expansion dates from the National Bureau of Economic Research (NBER). Since firms have different fiscal year-ends, we construct for each firm a yearly recession dummy which equals one if the fiscal year-end month for the firm is in a recession, and zero otherwise. ${ }^{15}$ Then, we examine the impact of business cycles on debt maturity by adding a recession dummy and the interaction term between the recession dummy and the systematic risk measure to equation (16).

To measure the changes in debt maturity over the business cycle, we need to remove the time variation in maturity due to secular trends. As shown in Figure 1, the trend component of aggregate debt maturity is U-shaped over the sample period. We include a quadratic deterministic time trend to control for this effect, where we assume that the loadings on the

\footnotetext{
${ }^{14}$ We obtain very similar results adjusting standard errors by clustering the observations in the same industry and in the same year.

${ }^{15}$ The results are quantitatively similar if we categorize a fiscal year as in recession when at least three months of the fiscal year are in recession.
} 
time trend are the same for all firms. The results are presented in Table 5.

In column (1), the long-term debt share is regressed on the recession dummy, asset market beta, and their interaction term after controlling for asset volatility, book leverage, and other firm characteristics. The coefficient estimate of the recession dummy is -0.042 , while the coefficient of the interaction term between asset market beta and the recession dummy is 0.026. Taken together, these values imply that (a) the long-term debt share of an average firm drops by about $1.9 \%$ from expansions to recessions (based on the average market beta of 0.879); (b) for a firm with an asset market beta at the 10th percentile, its long-term debt share is $3.7 \%$ lower from expansions to recessions, whereas the long-term debt share of a firm with asset market beta at the 90th percentile is essentially unchanged from expansions to recessions. In column (2), replacing the quadratic time trend with the trend component from the Hodrick-Prescott filter generates almost identical results.

The regression results using asset bank betas and tail betas are in columns (3) - (4). The coefficient estimates of the interaction term between the asset bank beta and the recession dummy and the interaction term between the asset tail beta and the recession dummy are both positive and statistically significant. The economic significance of the coefficient estimates are comparable to those obtained for the asset market beta.

Our model predictions not only apply to changes in the business cycle, but also to other changes in macroeconomic conditions that result in significant changes in the risk premium. One commonly used proxy of the aggregate risk premium is the market volatility index. Thus, we use VXO, the implied volatility of the S\&P 100 options (a close cousin to the better-known VIX index based on the S\&P 500 options but with a longer sample), as an alternative measure of macroeconomic conditions. As columns (5) - (7) of Table 5 show, the main finding that debt maturity becomes more sensitive to systematic risk during times of high risk premium still holds.

In the analysis presented so far, we allow the impact of business cycles on debt maturity to depend only on firms' exposure to systematic risk. However, changes in macroeconomic conditions could also affect the relation between debt maturity and other firm characteristics. 
We find that, in addition to low beta firms, firms with large size and low default probability reduce their debt maturity more from expansions to recessions. This is consistent with the finding of Mian and Santos (2011) that credit worthy firms are more likely not to rollover their long-term debt in bad times. As Table 2 shows, these characteristics are different from our systematic risk measures. On the other hand, we also find that firms with high book leverage reduce maturity more in recessions. This is consistent with Diamond (1991) in that firms with very low credit quality might only be able to issue short-term debt in bad times. The details of these analyses are in Table A.2 of Appendix C. Other robustness checks in Appendix $\mathrm{C}$ include the regression results for alternative measures of debt maturity (Table A.3), and for the sample period excluding the recent financial crisis (Table A.4).

A few questions remain. First, do high-beta firms end up with longer debt maturity by issuing longer-maturity debt? The answer is yes. Using the FISD issuance data of public bonds, we find that firms with high systematic risk are indeed more likely to issue long-term bonds in normal times. The relation between bond issuance and systematic risk is not significant in economic downturns, which could be due to firms switching from public bond issuance to bank loans and lines of credit in recessions.

Second, how do firms actually reduce debt maturity in bad times? One possibility is that firms do not rollover the long-term debt that matures during a recession. Then, the maturity for the remaining debt will drop mechanically over time. This would imply that total amount of debt declines in recessions. Another possibility is that firms replace maturing long-term debt with short-term debt. As a result, the total amount of debt is largely unchanged, as is assumed in our model. Mian and Santos (2011) show that credit worthy firms do exactly this: instead of rolling over long-term debt in bad times, they draw down on the lines of credit commitment. We find that (1) book leverage has very small difference between expansions and recessions across firms sorted on beta; (2) cross-sectional correlation between changes in debt maturity and changes in book leverage is insignificantly different from zero. These results support our modeling of debt maturity in Section 2.

Another potential concern is that our measure of debt maturity can be affected by callability. For example, if firms with high asset beta tend to issue more callable debt than 
do low-beta firms, then the effective debt maturity for the high-beta firms could be shorter than low-beta firms even though their stated maturity is longer. Similarly, if firms issue more callable debt in good times than in bad times, then their effective maturity may not necessarily be pro-cyclical. To address this concern, we collect issuance data for callable and noncallable bonds from FISD and estimate a logit model of callable bond issuance on firm characteristics. The results show that the tendency to issue callable bonds is unrelated to our firm-level systematic risk measures. ${ }^{16}$ Moreover, with the exception of the 1990 recession, the share of callable debt in issuance is unrelated to the business cycle.

Finally, we have computed our asset beta measures by unlevering the equity betas according to the Merton model. This procedure ignores the heterogeneity in debt maturity across firms, which could mechanically generate a relation between the unlevered asset beta and debt maturity even if the true asset beta is unrelated to debt maturity. Our model shows in which direction this bias goes. For the same asset beta, a longer debt maturity lowers the firm's equity beta. This is especially true for high leverage firms. That means if we ignore the heterogeneity in debt maturity when unlevering the equity beta, we would understate the asset beta for those firms with long maturity, which biases us against finding a positive relationship between asset beta and debt maturity. Moreover, all of our results hold in the sub-sample of firms with below-median leverage, where the effects of debt maturity on the unlevering procedure is negligible.

\subsection{Term Structure of Credit Spreads}

In this section, we test our model's predictions of the effect of debt maturity dynamics on the term structure of credit spreads. Specifically, we treat the 2008 financial crisis/recession as a significant change in macroeconomic conditions and examine the resulting changes in credit spreads for firms with different maturity structures, leverage, and systematic risk exposures.

We obtain firm-level credit default swap (CDS) spreads with maturity 1 year, 5 years, and 10 years from Markit, and match the data with the COMPUSTAT information. We

\footnotetext{
${ }^{16}$ Nondurable and service firms do issue more callable bonds, implying the effective maturity for these firms might be shorter, which would further strengthen our finding.
} 
follow Almeida, Campello, Laranjeira, and Weisbenner (2011) and treat August 2007 as the onset of the financial crisis. Changes in the CDS spreads during the crisis are measured as the differences in the averages of daily CDS spreads between fiscal year 2007 and 2008. Next, we use the 2007 fiscal year balance sheet information to compute the proportion of long-term debt that matures in $2008($ ldebt08 $=d d 1 /(d d 1+d l t t))$. The larger this measure, the more the debt maturity could be reduced in the crisis, hence the higher the rollover risk the firm faces. To ensure that the fiscal year 2008 of a firm starts within the crisis, we focus on firms that have the 2007 fiscal year-end months in September, October, November, December, or January. The sample of firms with these fiscal year-end months corresponds to $87 \%$ of the 375 firms with CDS data in both fiscal year 2007 and 2008.

We then examine the cross-sectional relation between the changes in the CDS spreads from 2007 to 2008 (using the CDS spreads with maturity 1 year, 5 years, and 10 years respectively) and firms' maturity structures in 2007. The financial crisis could exacerbate default risk through other firm characteristics. Consequently, we also control for firm characteristics including market leverage, asset volatility, firm size, market-to-book ratio, profitability, tangibility, equity return (past 12 months), credit rating (from the Standard \& Poor's), and industry dummies (1-digit SIC code) in the regression. ${ }^{17}$

Our model predicts that a larger reduction in debt maturity leads to larger increases in credit spreads in the crisis. For firms with lumpy maturity structure, those who have a large amount of debt due in a crisis will have larger increases in credit risk. Both predictions suggest a positive relation between the maturity measure ldebt08 and changes in credit spreads during the crisis. In addition, our model predicts that the maturity effect on credit spreads is more pronounced for firms with high leverage or high systematic risk. To test these additional predictions, we split firms into two groups by dividing the sample at the median of pre-crisis market leverage, book leverage, and cash flow beta, respectively. We then run the regression for firms in each group separately. The regression results are presented in Table 6. We also use the coefficient estimates to compute the implied impact of a one-standard deviation

\footnotetext{
${ }^{17} \mathrm{We}$ convert the credit rating into a numerical scale as follows: 1-AAA+, 2-AAA, 3-AA+, 4-AA, 5-AA-, 6-A+, 7-A, 8-A-, 9-BBB+, 10-BBB, 11-BBB-, 12-BB+, 13-BB, 14-BB-, 15-B+, 16-B, 17-B-, 18-CCC+, 19-CCC, 20-CCC-, 21-CC, and 22-C.
} 
A. Book leverage-sorted firms

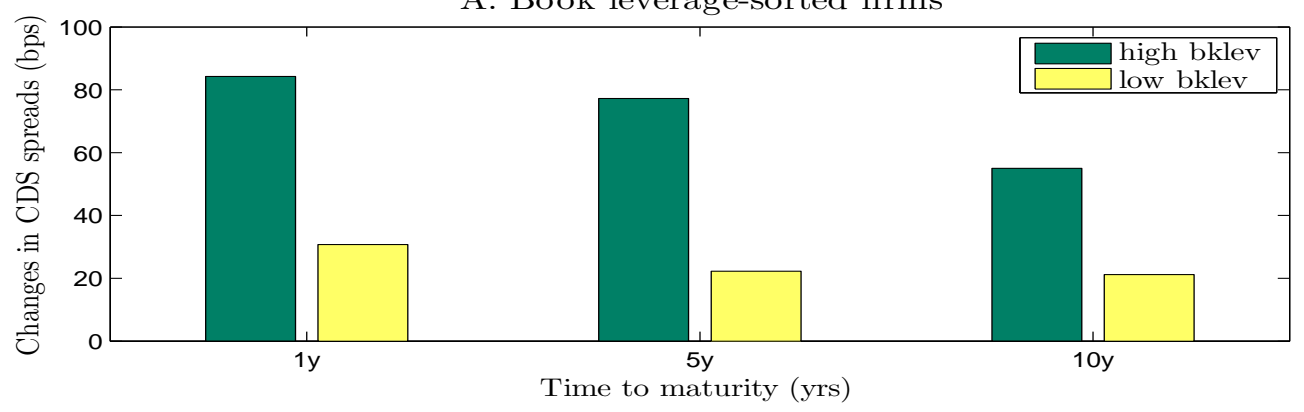

B. Cash flow beta-sorted firms

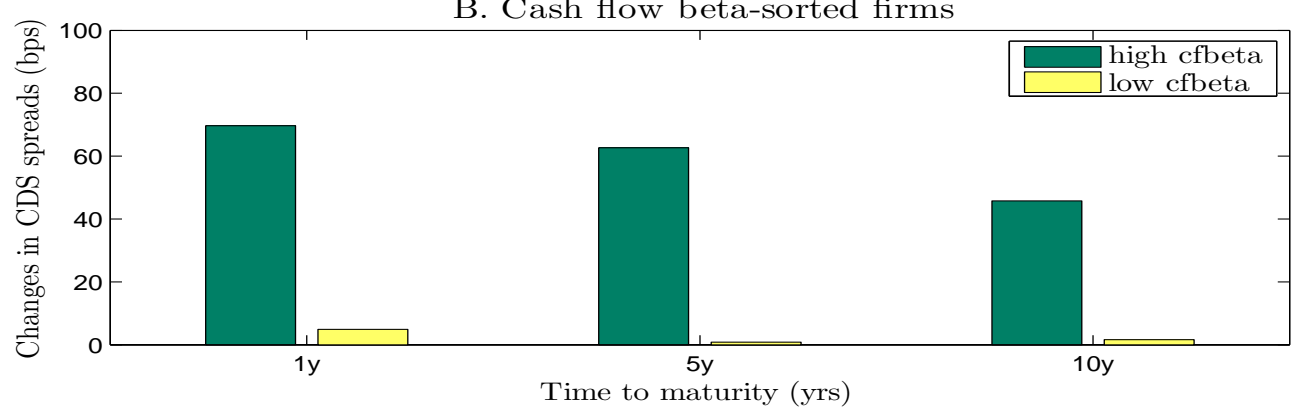

Figure 9: Impact of long-term debt structure on credit spreads. This graph shows the impact of a one-standard deviation increase in the proportion of long-term debt that matures in 2008 on the changes in the CDS spreads between 2007 and 2008. Panels A and B display the result for firms sorted on book leverage and cash-flow beta, respectively.

increase in ldebt 08 on changes in the CDS spreads and present the results in Figure 9.

The results show that a firm with a larger portion of its long-term debt maturing in 2008 experiences a more significant increase in CDS spreads. A one-standard deviation increase in ldebt08 for the fiscal year 2007 corresponds to a 50 bps, 40 bps and 32 bps increase in the CDS spreads with maturity of 1 year, 5 years, and 10 years respectively in 2008. These results are consistent with the empirical findings in $\mathrm{Hu}$ (2010).

We also find evidence that the maturity reduction amplifies the impact of aggregate shocks on the credit spreads more for firms with higher leverage and higher beta before the crisis. Panel A of Figure 9 shows that a one-standard deviation increase in ldebt08 raises the 1-year, 5-year, and 10-year CDS spreads by 84 bps, 77 bps, and 55 bps respectively for firms with above-median book leverage, while the corresponding increase in the CDS spreads is 31 bps, 22 bps, and 21 bps respectively for firms with below-median book leverage. The results 
are similar if we sort firms based on market leverage (see Table 6). Panel B shows the result for cash flow beta-sorted firms. A one-standard deviation increase in ldebt08 raises 1-year, 5-year, and 10-year the CDS spreads by $70 \mathrm{bps}, 63 \mathrm{bps}$, and 46 bps respectively for firms with high cash flow beta, while the corresponding increase in the CDS spreads is negligible for firms with low cash flow beta.

One concern about our measure of long-term debt structure in 2007 is its endogeneity. Long-term debt is usually held by various investors and very difficult to renegotiate on short notice, which suggests the long-term debt structure is not easy to adjust. However, Mian and Santos (2011) show that firms with good credit quality did actively manage the maturity of syndicated loans before the financial crisis through early refinancing of outstanding loans. This would imply that those firms with high rollover risk according to ldebt08 could be the firms with low quality (which are not captured by the controls), which would explain the larger increase in their credit spreads during the crisis. To address this concern, we compute ldebt08 based on balance sheet information from fiscal years $2004(d d 4 /(d d 1+d l t t)), 2005$ $(d d 3 /(d d 1+d l t t))$, and $2006(d d 2 /(d d 1+d l t t))$. We then run cross-sectional regression of changes in the CDS spreads from 2007 to 2008 on ldebt08, industry dummies, and other firm controls measured at the end of the fiscal years 2004-2006, respectively. We obtain almost identical results based on the fiscal year 2006 information. The results are slightly weaker for 2005 but no longer significant for 2004.

\section{Concluding Remarks}

Firms' maturity choices are closely linked to their systematic risk exposures and macroeconomic conditions. We build a model to explain the dynamic relation between debt maturity and systematic risk, as well as their implications for the term structure of credit risk. We also provide empirical evidence for the model predictions.

While we have focused on debt maturity in this paper, there are many dimensions firms

can manage their exposures to macroeconomic risks, including other financing decisions such as cash holding, lines of credit, payout, and real decisions such investments and mergers and 
acquisitions (see e.g., Acharya, Almeida, and Campello (2012), Bolton, Chen, and Wang (2012)). To understand the data, ultimately we need to jointly study the firms' decisions in all these dimensions. Next, as a starting point, our modeling of the maturity structure dynamics is still quite stylized, especially for the purpose of pricing credit-risky securities. It would be very useful to extend the model to capture more realistic maturity structures. 


\section{References}

Acharya, V. V., H. Almeida, and M. Campello, 2012, "Aggregate Risk and the Choice between Cash and Line of Credit," forthcoming, Journal of Finance.

Almeida, H., M. Campello, B. Laranjeira, and S. Weisbenner, 2011, "Corporate Debt Maturity and the Real Effects of the 2007 Credit Crisis," Critical Finance Review, 1, 3-58.

Almeida, H., and T. Philippon, 2007, "The Risk-Adjusted Cost of Financial Distress," Journal of Finance, 62, 2557-2586.

Baker, M., R. Greenwood, and J. Wurgler, 2003, "The Maturity of Debt Issues and Predictable Variation in Bond Returns," Journal of Financial Economics, 70, 261-291.

Bansal, R., and A. Yaron, 2004, "Risks for the Long Run: A Potential Resolution of Asset Pricing Puzzles," Journal of Finance, 59, 1481 - 1509.

Bao, J., J. Pan, and J. Wang, 2011, "The Illiquidity of Corporate Bonds," Journal of Finance, 66, 911-946.

Barclay, M. J., and C. W. Smith, 1995, "The Maturity Structure of Corporate Debt," Journal of Finance, 50, 609-931.

Barlow, M. T., L. C. G. Rogers, and D. Williams, 1980, Wiener-Hopf Factorization for Matrices, in Séminaire de Probabilités XIV, Lecture Notes in Math. 784 . pp. 324-331, Springer-Verlag, Berlin.

Bhamra, H. S., L.-A. Kuehn, and I. A. Strebulaev, 2010a, "The Aggregate Dynamics of Capital Structure and Macroeconomic Risk," Review of Financial Studies, 23, 4187-4241.

Bhamra, H. S., L.-A. Kuehn, and I. A. Strebulaev, 2010b, "The Levered Equity Risk Premium and Credit Spreads: A Unified Framework," Review of Financial Studies, 23, 645-703.

Bharath, S. T., and T. Shumway, 2008, "Forecasting Default with Merton Distance to Default Model," Review of Financial Studies, 21, 1339-1369. 
Bolton, P., H. Chen, and N. Wang, 2012, "Market Timing, Investment, and Risk Management," Working Paper.

Chen, H., 2010, "Macroeconomic Conditions and the Puzzles of Credit Spreads and Capital Structure," Journal of Finance, 65, 2171-2212.

Chen, H., and G. Manso, 2010, "Macroeconomic Risk and Debt Overhang," Working Paper, MIT.

Chen, L., P. Collin-Dufresne, and R. S. Goldstein, 2009, "On the Relation Between the Credit Spread Puzzle and the Equity Premium Puzzle," Review of Financial Studies, 22, 3367-3409.

Chen, L., D. A. Lesmond, and J. Wei, 2007, "Corporate Yield Spreads and Bond Liquidity," Journal of Finance, 62, 119-149.

Choi, J., D. Hackbarth, and J. Zechner, 2012, "Granularity of Corporate Debt: Theory and Tests," Working paper.

Collin-Dufresne, P., and R. S. Goldstein, 2001, "Do Credit Spreads Reflect Stationary Leverage Ratios?," Journal of Finance, 56, 1929-1957.

Diamond, D. W., 1991, "Debt Maturity Structure and Liquidity Risk," Quarterly Journal of Economics, 106, 709-737.

Duffie, D., and D. Lando, 2001, "Term Structures of Credit Spreads with Incomplete Accounting Information," Econometrica, 69, 633-664.

Duffie, D., and K. Singleton, 1999, "Modeling Term Structures of Defaultable Bonds," Review of Financial Studies, 12, 687-720.

Edwards, A. K., L. E. Harris, and M. S. Piwowar, 2007, "Corporate Bond Market Transaction Costs and Transparency," Journal of Finance, 62, 1421-1451.

Erel, I., B. Julio, W. Kim, and M. S. Weisbach, 2012, "Macroeconomic Conditions and Capital Raising," Review of Financial Studies, 25, 341-376. 
Flannery, M. J., 1986, "Asymmetric Information and Risky Debt Maturity Choice," Journal of Finance, 41, 19-37.

Gomes, J. F., L. Kogan, and M. Yogo, 2009, "Durability of Output and Expected Stock Returns," Journal of Political Economy, 117, 941-986.

Gomes, J. F., and L. Schmid, 2010, "Equilibrium Credit Spreads and the Macroeconomy," Working Paper, University of Pennsylvania.

Greenwood, R., S. Hanson, and J. C. Stein, 2010, "A Gap-Filling Theory of Corporate Debt Maturity Choice," Journal of Finance, 65, 993-1028.

Guedes, J., and T. Opler, 1996, "The Determinants of the Maturity of Corporate Debt Issues," Journal of Finance, 51, 1809-1833.

He, Z., and K. Milbradt, 2012, "Endogenous Liquidity and Defaultable Bonds," Working Paper, University of Chicago and MIT.

Helwege, J., and C. M. Turner, 1999, "The Slope of the Credit Yield Curve for SpeculativeGrade Issuers," Journal of Finance, 54, 1869-1884.

Hu, X., 2010, "Rollover Risk and Credit Spreads in the Financial Crisis of 2008," Working paper, Princeton University.

Jarrow, R. A., D. Lando, and S. M. Turnbull, 1997, "A Markov Model for the Term Structure of Credit Risk Spreads," Review of Financial Studies, 10, 481-523.

Jobert, A., and L. Rogers, 2006, "Option Pricing with Markov-Modulated Dynamics," SIAM Journal on Control and Optimization, 44, 2063-2078.

Lando, D., 1998, "On Cox Processes and Credit Risky Securities," Review of Derivatives Research, 2, 99-120.

Leland, H., 1994, "Corporate Debt Value, bond covenants, and Optimal Capital Structure," Journal of Finance, 49, 1213-1252. 
Leland, H., 1998, "Agency Costs, Risk Management, and Capital Structure," Journal of Finance, 53, 1213-1243.

Leland, H., and K. B. Toft, 1996, "Optimal Capital Structure, Endogenous Bankruptcy, and the Term Structure of Credit Spreads," Journal of Finance, 51, 987-1019.

Longstaff, F. A., S. Mithal, and E. Neis, 2005, "Corporate Yield Spreads: Default Risk or Liquidity? New Evidence from the Credit Default Swap Market," Journal of Finance, 60, 2213-2253.

Merton, R. C., 1974, "On the Pricing of Corporate Debt: the Risk Structure of Interest Rates," Journal of Finance, 29, 449-470.

Mian, A., and J. A. Santos, 2011, "Liquidity Risk and Maturity Management Over The Credit Cycle," Working Paper, University of California, Berkeley.

Miller, M. H., 1977, "Debt and Taxes," Journal of Finance, 32, 261-275.

Newey, W. K., and K. D. West, 1987, "A Simple, Positive Semi-definite, Heteroskedasticity and Autocorrelation Consistent Covariance Matrix," Econometrica, 55, 703-708.

Stohs, M. H., and D. C. Mauer, 1996, "The Determinants of Corporate Debt Maturity Structure," Journal of Business, 69, 279-312.

Strebulaev, I. A., 2007, "Do Tests of Capital Structure Theory Mean What They Say?," Journal of Finance, 62, 1747-1787.

Vassalou, M., and Y. Xing, 2004, "Default Risk in Equity Returns," Journal of Finance, 59, $831-868$.

Zhou, C., 2001, "The Term Structure of Credit Spreads with Jump Risk," Journal of Banking and Finance, 25, 2015-2040. 
Table 1: Baseline model parameters and results. Panel A contains the parameters used in the baseline model and the results on capital structure and credit spreads. Parameters that do not vary across the states include: $\kappa=\ln 2.5, \sigma_{f}=0.23, C / P=0.05, \tau=0.2$. All parameters are annualized if applicable. Panel B summarizes results from the baseline calibration. Market betas are calculated assuming a leverage ratio of $\phi=1.25$ relative to cash flow parameters of the baseline firm which implies market dividend growth rate of $6.36 \%$ and $0.67 \%$ in states $G$ and $B$, and dividend volatilities of $17.0 \%$ and $19.4 \%$ in states $G$ and $B$ respectively. The initial capital structure choices are determined in state $G$.

\begin{tabular}{lcc}
\hline \multicolumn{3}{c}{ A. Baseline parameters } \\
\hline & state $G$ & state $B$ \\
\cline { 2 - 3 } Transition intensities: $\pi_{s}^{\mathbb{P}}$ & 0.1 & 0.5 \\
Riskfree rate: $r(s)$ & 0.056 & 0.026 \\
Market price of Brownian risk: $\eta(s)$ & 0.15 & 0.24 \\
Cash flow expected growth rate: $\mu^{\mathbb{P}}(s)$ & 0.062 & 0.016 \\
Cash flow systematic volatility: $\sigma_{\Lambda}(s)$ & 0.136 & 0.156 \\
Recovery rate: $\alpha(s)$ & 0.72 & 0.59 \\
Non-default spread parameter: $\ell_{0}(s)$ & $6.11 E-6$ & $3.56 E-3$ \\
Non-default spread parameter: $\ell_{1}(s)$ & 0.592 & 0.104 \\
\hline
\end{tabular}

B. Baseline model results

\begin{tabular}{lcc}
\hline & state $G$ & state $B$ \\
\cline { 2 - 3 } Initial market leverage: $D / V$ & $29.2 \%$ & $32.4 \%$ \\
Initial interest coverage: $y_{0} / C$ & 2.6 & 2.6 \\
Debt maturity: $1 / m_{s}$ & 5.5 & 5.0 \\
5 year default rate & $0.7 \%$ & $1.2 \%$ \\
10 year default rate & $4.6 \%$ & $6.0 \%$ \\
5 year credit spread & $31.7 \mathrm{bps}$ & $58.8 \mathrm{bps}$ \\
10 year credit spread & $102.6 \mathrm{bps}$ & $141.1 \mathrm{bps}$ \\
Conditional equity Sharpe ratio & 0.12 & 0.22 \\
\hline
\end{tabular}


Table 2: Summary Statistics and Correlations. This table presents descriptive statistics (Panel A) of firm-level variables (definitions see Appendix B) and Pearson correlations (Panel B) among risk measures.

\begin{tabular}{|c|c|c|c|c|c|c|}
\hline \multicolumn{7}{|c|}{ A. Summary statistics } \\
\hline & mean & std & median & $25 \%$ & $75 \%$ & obs \\
\hline ldebt1y & 0.737 & 0.287 & 0.852 & 0.611 & 0.954 & 94,618 \\
\hline ldebt2y & 0.631 & 0.306 & 0.723 & 0.436 & 0.878 & 71,649 \\
\hline ldebt3y & 0.525 & 0.315 & 0.580 & 0.265 & 0.785 & 71,649 \\
\hline ldebt4y & 0.434 & 0.310 & 0.450 & 0.137 & 0.687 & 71,649 \\
\hline ldebt5y & 0.349 & 0.295 & 0.323 & 0.045 & 0.581 & 71,649 \\
\hline debtmat & 4.762 & 2.595 & 4.733 & 2.547 & 6.835 & 71,649 \\
\hline mkat & 5.580 & 2.055 & 5.398 & 4.032 & 7.006 & 92,932 \\
\hline abnearn & 0.014 & 0.261 & 0.009 & -0.038 & 0.050 & 84,068 \\
\hline bklev & 0.299 & 0.171 & 0.271 & 0.165 & 0.399 & 94,618 \\
\hline $\mathrm{mk} 2 \mathrm{bk}$ & 1.583 & 1.157 & 1.218 & 0.953 & 1.735 & 92,932 \\
\hline assetmat & 4.584 & 4.692 & 3.086 & 1.805 & 5.444 & 91,175 \\
\hline profitvol & 0.063 & 0.064 & 0.042 & 0.024 & 0.075 & 67,818 \\
\hline mertondd & 5.542 & 4.002 & 4.788 & 2.596 & 7.633 & 63,568 \\
\hline asset market beta & 0.879 & 0.637 & 0.798 & 0.454 & 1.201 & 64,827 \\
\hline asset bank beta & 0.507 & 0.450 & 0.471 & 0.230 & 0.745 & 64,827 \\
\hline asset tail beta & 0.669 & 0.607 & 0.618 & 0.270 & 1.009 & 64,517 \\
\hline equity market beta & 1.128 & 0.746 & 1.068 & 0.659 & 1.518 & 64,827 \\
\hline cash flow beta & 1.773 & 2.590 & 1.410 & 0.105 & 3.260 & 21,507 \\
\hline assetvol & 0.386 & 0.198 & 0.338 & 0.255 & 0.462 & 64,827 \\
\hline sys assetvol & 0.138 & 0.095 & 0.121 & 0.068 & 0.187 & 64,827 \\
\hline id assetvol & 0.347 & 0.181 & 0.301 & 0.221 & 0.423 & 64,827 \\
\hline \multicolumn{7}{|c|}{ B. Correlations } \\
\hline & market beta & bank beta & tail beta & equity beta & cf beta & assetvol \\
\hline bank beta & 0.707 & & & & & \\
\hline tail beta & 0.460 & 0.328 & & & & \\
\hline equity beta & 0.917 & 0.662 & 0.369 & & & \\
\hline cf beta & 0.104 & 0.071 & 0.030 & 0.126 & & \\
\hline assetvol & 0.408 & 0.174 & 0.170 & 0.343 & 0.046 & \\
\hline mertondd & 0.032 & 0.036 & 0.154 & -0.186 & -0.081 & -0.390 \\
\hline
\end{tabular}




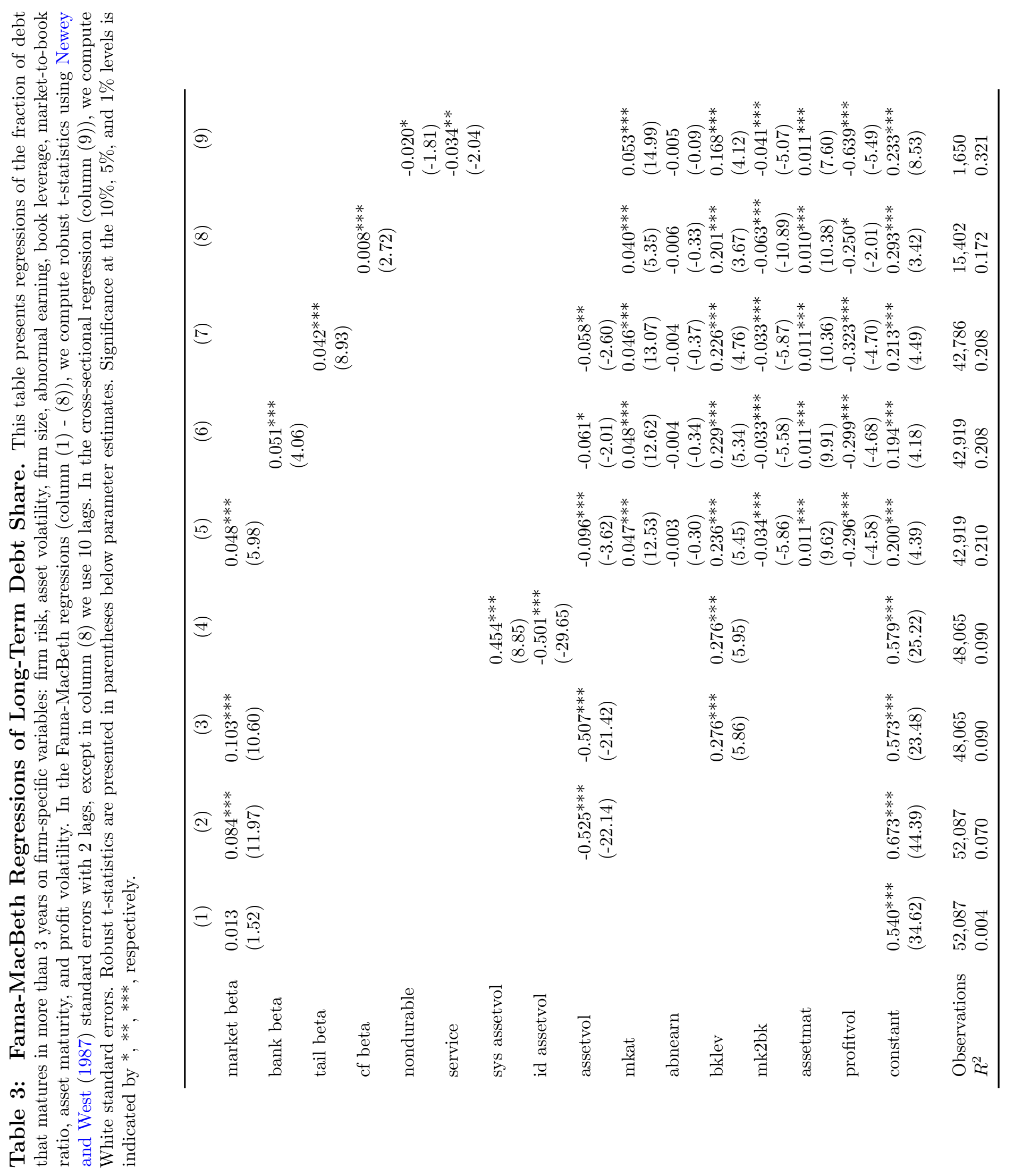


Table 4: Panel Regressions of Long-Term Debt Share. This table presents panel regressions of the fraction of debt that matures in more than 3 years on firm-specific variables: firm risk, asset volatility, firm size, abnormal earning, book leverage, market-to-book ratio, asset maturity, and profit volatility. Industry-fixed effects and year-fixed effects are also included in the regression. We adjust standard errors by clustering the observations at the industry level. Robust t-statistics are presented in parentheses below parameter estimates. Significance at the $10 \%, 5 \%$, and $1 \%$ levels is indicated by $*, * *, * * *$, respectively.

\begin{tabular}{|c|c|c|c|c|c|c|}
\hline & (1) & (2) & $(3)$ & (4) & (5) & (6) \\
\hline market beta & $\begin{array}{l}0.074^{* * *} \\
(19.36)\end{array}$ & $\begin{array}{l}0.087^{* * *} \\
(21.51)\end{array}$ & $\begin{array}{l}0.041 * * * \\
(8.95)\end{array}$ & & & \\
\hline bank beta & & & & $\begin{array}{l}0.037^{* * *} \\
(6.08)\end{array}$ & & \\
\hline tail beta & & & & & $\begin{array}{l}0.036^{* * *} \\
(9.84)\end{array}$ & \\
\hline cf beta & & & & & & $\begin{array}{l}0.004^{* *} \\
(2.15)\end{array}$ \\
\hline assetvol & $\begin{array}{l}-0.426^{* * *} \\
(-23.21)\end{array}$ & $\begin{array}{l}-0.415^{* * *} \\
(-23.90)\end{array}$ & $\begin{array}{l}-0.063^{* * *} \\
(-3.44)\end{array}$ & $\begin{array}{l}-0.019 \\
(-0.98)\end{array}$ & $\begin{array}{l}-0.025 \\
(-1.30)\end{array}$ & \\
\hline mkat & & & $\begin{array}{l}0.047^{* * *} \\
(17.14)\end{array}$ & $\begin{array}{l}0.049^{* * * *} \\
(17.75)\end{array}$ & $\begin{array}{l}0.046^{* * *} \\
(17.20)\end{array}$ & $\begin{array}{l}0.044^{* * *} \\
(11.29)\end{array}$ \\
\hline abnearn & & & $\begin{array}{l}-0.015^{* * *} \\
(-3.43)\end{array}$ & $\begin{array}{l}-0.016^{* * *} \\
(-3.53)\end{array}$ & $\begin{array}{l}-0.014^{* * *} \\
(-3.11)\end{array}$ & $\begin{array}{l}-0.026^{* * *} \\
(-2.93)\end{array}$ \\
\hline bklev & & $\begin{array}{l}0.218^{* * *} \\
(8.59)\end{array}$ & $\begin{array}{l}0.240^{* * *} \\
(8.82)\end{array}$ & $\begin{array}{l}0.231^{* * * *} \\
(8.64)\end{array}$ & $\begin{array}{l}0.234^{* * *} \\
(8.73)\end{array}$ & $\begin{array}{l}0.274^{* * *} \\
(6.61)\end{array}$ \\
\hline $\mathrm{mk} 2 \mathrm{bk}$ & & & $\begin{array}{l}-0.019 * * * \\
(-4.22)\end{array}$ & $\begin{array}{l}-0.017^{* * *} \\
(-3.88)\end{array}$ & $\begin{array}{l}-0.020^{* * *} \\
(-4.54)\end{array}$ & $\begin{array}{l}-0.036^{* * *} \\
(-4.55)\end{array}$ \\
\hline assetmat & & & $\begin{array}{l}0.008^{* * *} \\
(7.85)\end{array}$ & $\begin{array}{l}0.008^{* * *} \\
(7.73)\end{array}$ & $\begin{array}{l}0.008^{* * *} \\
(7.70)\end{array}$ & $\begin{array}{l}0.005^{* * *} \\
(2.66)\end{array}$ \\
\hline profitvol & & & $\begin{array}{l}-0.333^{* * *} \\
(-4.73)\end{array}$ & $\begin{array}{l}-0.341^{* * *} \\
(-4.84)\end{array}$ & $\begin{array}{l}-0.345^{* * *} \\
(-4.84)\end{array}$ & $\begin{array}{l}-0.286^{* *} \\
(-2.11)\end{array}$ \\
\hline constant & $\begin{array}{l}0.638^{* * *} \\
(82.28)\end{array}$ & $\begin{array}{l}0.568^{* * *} \\
(52.72)\end{array}$ & $\begin{array}{l}0.200^{* * *} \\
(10.82)\end{array}$ & $\begin{array}{l}0.190^{* * *} \\
(10.02)\end{array}$ & $\begin{array}{l}0.205^{* * *} \\
(11.10)\end{array}$ & $\begin{array}{l}0.246^{* * *} \\
(7.63)\end{array}$ \\
\hline Industry Fixed-Effect & Yes & Yes & Yes & Yes & Yes & Yes \\
\hline Year Fixed-Effect & Yes & Yes & Yes & Yes & Yes & Yes \\
\hline Observations & 52,087 & 48,065 & 42,919 & 42,919 & 42,786 & 15,402 \\
\hline$R^{2}$ & 0.070 & 0.078 & 0.162 & 0.160 & 0.161 & 0.121 \\
\hline
\end{tabular}


Table 5: Long-Term Debt Share: Impact of Macroeconomic Conditions. This table presents regression results of the fraction of debt that matures in more than 3 years on a macroeconomic variable, asset beta, an interaction between the macroeconomic variable and asset beta, firm controls (total asset volatility, firm size, abnormal earning, book leverage, market-to-book ratio, asset maturity, and profit volatility) and industry dummies. We measure macroeconomic conditions using either a recession dummy dated by NBER or the S\&P 100 volatility index (VXO). We also include either a quadratic time trend or an aggregate trend generated by the H-P filter on the aggregate long-term debt share. We adjust standard errors by clustering the observations at the industry level. Robust t-statistics are presented in parentheses below parameter estimates. Significance at the $10 \%, 5 \%$, and $1 \%$ levels is indicated by ${ }^{*},{ }^{* *},{ }^{* * *}$, respectively.

\begin{tabular}{|c|c|c|c|c|c|c|c|}
\hline & \multicolumn{4}{|c|}{ Recession } & \multicolumn{3}{|c|}{$\mathrm{VXO}$} \\
\hline & (1) & (2) & $(3)$ & (4) & (5) & (6) & (7) \\
\hline macro & $\begin{array}{l}-0.042^{* * *} \\
(-5.48)\end{array}$ & $\begin{array}{l}-0.043^{* * *} \\
(-5.63)\end{array}$ & $\begin{array}{l}-0.039 * * * \\
(-5.72)\end{array}$ & $\begin{array}{l}-0.035^{* * *} \\
(-5.85)\end{array}$ & $\begin{array}{l}-0.001^{* * *} \\
(-2.95)\end{array}$ & $\begin{array}{l}-0.001^{* * *} \\
(-4.25)\end{array}$ & $\begin{array}{l}-0.001^{* * *} \\
(-2.60)\end{array}$ \\
\hline market beta & $\begin{array}{l}0.046^{* * *} \\
(10.25)\end{array}$ & $\begin{array}{l}0.044^{* * *} \\
(9.44)\end{array}$ & & & $\begin{array}{l}0.023^{* *} \\
(2.57)\end{array}$ & & \\
\hline market beta $\times$ macro & $\begin{array}{l}0.026^{* * * *} \\
(2.94)\end{array}$ & $\begin{array}{l}0.024^{* * *} \\
(2.75)\end{array}$ & & & $\begin{array}{l}0.001^{* *} \\
(2.20)\end{array}$ & & \\
\hline bank beta & & & $\begin{array}{l}0.041^{* * *} \\
(6.83)\end{array}$ & & & $\begin{array}{l}-0.001 \\
(-0.04)\end{array}$ & \\
\hline bank beta $\times$ macro & & & $\begin{array}{l}0.039^{* * *} \\
(3.17)\end{array}$ & & & $\begin{array}{l}0.001^{* * *} \\
(2.69)\end{array}$ & \\
\hline tail beta & & & & $\begin{array}{l}0.040^{* * *} \\
(11.06)\end{array}$ & & & $\begin{array}{l}0.026^{* * *} \\
(2.67)\end{array}$ \\
\hline tail beta $\times$ macro & & & & $\begin{array}{l}0.019^{* *} \\
(2.47)\end{array}$ & & & $\begin{array}{l}0.001^{*} \\
(1.66)\end{array}$ \\
\hline assetvol & $\begin{array}{l}-0.106^{* * *} \\
(-6.42)\end{array}$ & $\begin{array}{l}-0.108^{* * *} \\
(-6.18)\end{array}$ & $\begin{array}{l}-0.062^{* * *} \\
(-3.51)\end{array}$ & $\begin{array}{l}-0.063^{* * *} \\
(-3.66)\end{array}$ & $\begin{array}{l}-0.086^{* * *} \\
(-4.59)\end{array}$ & $\begin{array}{l}-0.042^{* *} \\
(-2.11)\end{array}$ & $\begin{array}{l}-0.055^{* * *} \\
(-2.68)\end{array}$ \\
\hline mkat & $\begin{array}{l}0.046^{* * *} \\
(17.20)\end{array}$ & $\begin{array}{l}0.044^{* * *} \\
(17.75)\end{array}$ & $\begin{array}{l}0.047^{* * * *} \\
(17.48)\end{array}$ & $\begin{array}{l}0.045^{* * *} \\
(17.02)\end{array}$ & $\begin{array}{l}0.053^{* * *} \\
(16.92)\end{array}$ & $\begin{array}{l}0.055^{* * *} \\
(17.42)\end{array}$ & $\begin{array}{l}0.052^{\text {*** }} \\
(17.10)\end{array}$ \\
\hline abnearn & $\begin{array}{l}-0.015^{* * *} \\
(-3.42)\end{array}$ & $\begin{array}{l}-0.016^{* * *} \\
(-3.41)\end{array}$ & $\begin{array}{l}-0.016^{* * *} \\
(-3.61)\end{array}$ & $\begin{array}{l}-0.015^{* * *} \\
(-3.16)\end{array}$ & $\begin{array}{l}-0.020^{* * *} \\
(-3.14)\end{array}$ & $\begin{array}{l}-0.021^{* * *} \\
(-3.18)\end{array}$ & $\begin{array}{l}-0.018^{* * *} \\
(-2.79)\end{array}$ \\
\hline bklev & $\begin{array}{l}0.233^{* * *} \\
(8.43)\end{array}$ & $\begin{array}{l}0.234^{* * *} \\
(8.41)\end{array}$ & $\begin{array}{l}0.218^{* * * *} \\
(8.02)\end{array}$ & $\begin{array}{l}0.223^{* * *} \\
(8.18)\end{array}$ & $\begin{array}{l}0.323^{* * *} \\
(10.36)\end{array}$ & $\begin{array}{l}0.310^{* * *} \\
(10.21)\end{array}$ & $\begin{array}{l}0.322^{* * *} \\
(10.61)\end{array}$ \\
\hline $\mathrm{mk} 2 \mathrm{bk}$ & $\begin{array}{l}-0.018^{* * *} \\
(-4.20)\end{array}$ & $\begin{array}{l}-0.018^{* * *} \\
(-4.10)\end{array}$ & $\begin{array}{l}-0.015^{* * *} \\
(-3.57)\end{array}$ & $\begin{array}{l}-0.018^{* * *} \\
(-4.44)\end{array}$ & $\begin{array}{l}-0.017^{* * *} \\
(-3.83)\end{array}$ & $\begin{array}{l}-0.014^{* * *} \\
(-3.34)\end{array}$ & $\begin{array}{l}-0.018^{* * *} \\
(-4.12)\end{array}$ \\
\hline asset mat & $\begin{array}{l}0.008^{* * * *} \\
(8.12)\end{array}$ & $\begin{array}{l}0.008^{* * *} \\
(7.99)\end{array}$ & $\begin{array}{l}0.008^{* * * *} \\
(8.01)\end{array}$ & $\begin{array}{l}0.008^{* * *} \\
(7.94)\end{array}$ & $\begin{array}{l}0.007^{* * *} \\
(6.14)\end{array}$ & $\begin{array}{l}0.007^{* * *} \\
(6.03)\end{array}$ & $\begin{array}{l}0.007^{* * *} \\
(6.00)\end{array}$ \\
\hline profitvol & $\begin{array}{l}-0.307^{* * *} \\
(-4.62)\end{array}$ & $\begin{array}{l}-0.320^{* * *} \\
(-5.00)\end{array}$ & $\begin{array}{l}-0.315^{* * *} \\
(-4.73)\end{array}$ & $\begin{array}{l}-0.321^{* * *} \\
(-4.82)\end{array}$ & $\begin{array}{l}-0.271^{* * *} \\
(-3.73)\end{array}$ & $\begin{array}{l}-0.280^{* * *} \\
(-3.82)\end{array}$ & $\begin{array}{l}-0.284^{* * *} \\
(-4.00)\end{array}$ \\
\hline Quadratic Trend & Yes & No & Yes & Yes & Yes & Yes & Yes \\
\hline HP Trend & No & Yes & No & No & No & No & No \\
\hline Industry Fixed-Effect & Yes & Yes & Yes & Yes & Yes & Yes & Yes \\
\hline Observations & 42,919 & 42,919 & 42,919 & 42,786 & 26,748 & 26,748 & 26,667 \\
\hline$R^{2}$ & 0.154 & 0.155 & 0.151 & 0.153 & 0.173 & 0.170 & 0.173 \\
\hline
\end{tabular}


Table 6: Long-Term Debt Structure and Credit Spreads. This table presents crosssectional regression results of yearly changes in CDS spreads from fiscal year 2007 to 2008 on the proportion of long-term debt maturing in 2008, firm controls (market leverage, total asset volatility, firm size, marketto-book ratio, profitability, tangible, equity return, and credit rating), and industry dummies based on the 1-digit SIC code. The regressions are estimated for the entire sample and separately for sub-samples of firms formed on the basis of firm characteristics at the end of fiscal year 2007. For three firm characteristics, the sub-samples comprise firms with market leverage, book leverage, and cash flow beta above and below the sample median, respectively. Only coefficient estimates of variables that are consistently statistically significant cross different specifications are reported. Robust t-statistics are presented in parentheses below parameter estimates. Significance at the $10 \%, 5 \%$, and $1 \%$ levels is indicated by $*,{ }^{* *},{ }^{* * *}$, respectively.

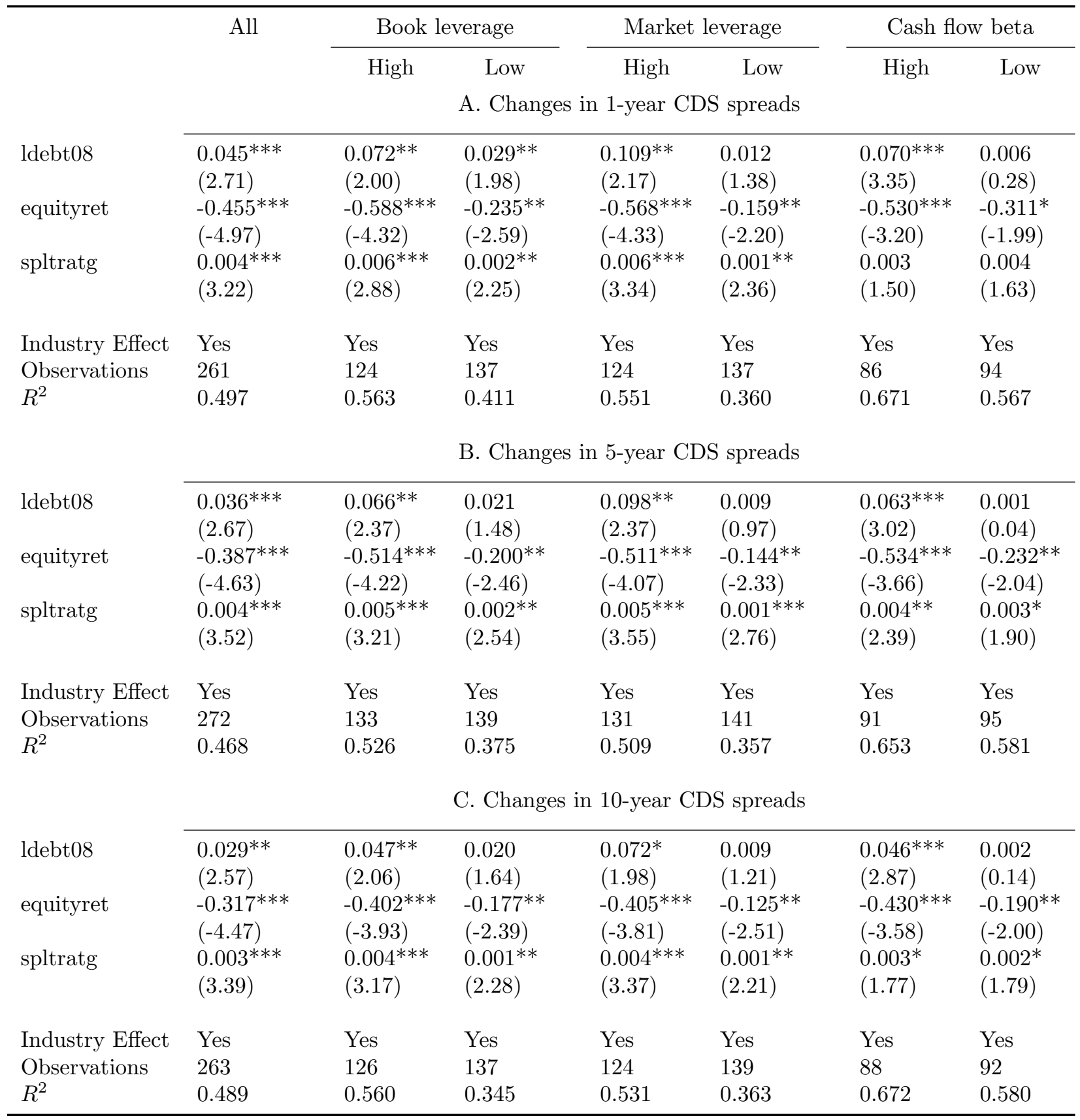




\section{Appendix}

\section{A Model Solution}

This section contains solutions to a generalized model which includes, as special cases, both the baseline 2 state model as well as the 4 state lumpy maturity structure model of Section 2 . There is a total of $\mathcal{S}$ states, whose risk neutral transition intensities are summarized by the matrix $\boldsymbol{\Pi}^{18}$. We also allow parameters to be state dependent: for example, the state dependent risk neutral drifts will be summarized by a $\mathcal{S}$ by 1 vector $\boldsymbol{\mu}$; similar conventions will apply for other parameters. Capital structure choices will imply the tuple $(\mathbf{P}, \mathbf{C}, \mathbf{m}, \boldsymbol{\ell}, \mathbf{\Pi})$ which summarizes, respectively, the state dependent face value of debt, coupons, debt rollover intensities, liquidity costs and the transition matrix. The latter two quantities will, in general, depend on maturity structure.

Valuation equations. The valuation equations will be in terms of $\log$ cash flows $x=\log y$. Given the capital structure, external financing costs $\boldsymbol{\ell}$ and bankruptcy boundaries $\mathbf{x}_{D}=$ $\left\{x_{D}(s)\right\}_{s=1, \ldots, \mathcal{S}}$, debt value at issue, $\mathbf{D}(x)=\{D(x, s)\}_{s=1, \ldots, \mathcal{S}}$, is characterized by the following boundary value problem:

$$
\begin{aligned}
\mathbf{W}_{D} \mathbf{D}(x) & =\mathbf{C}+\mathbf{m} \odot \mathbf{P}+\mathbf{U D}^{\prime}(x)+\mathbf{V D}^{\prime \prime}(x) \\
D\left(x_{D}(s), s\right) & =\alpha(s) v^{*}(x) e^{x_{D}(x)}, \forall s=1, \ldots, \mathcal{S}
\end{aligned}
$$

where we define $\mathbf{W}_{D}=\operatorname{diag}(\mathbf{r})+\operatorname{diag}(\mathbf{m})+\operatorname{diag}(\boldsymbol{\ell})-\boldsymbol{\Pi}, \mathbf{U}=\operatorname{diag}\left(\boldsymbol{\mu}-\frac{1}{2} \boldsymbol{\sigma} \odot \boldsymbol{\sigma}\right)$ and $\mathbf{V}=\operatorname{diag}\left(\frac{1}{2} \boldsymbol{\sigma} \odot \boldsymbol{\sigma}\right)$. We take $\odot$ to mean element-wise multiplication and functions of vectors are applied element-wise. The vector $\mathbf{v}^{*}$ is the firm to cash flow value for the unlevered firm and is given by the generalized Gordon growth formula.

Similarly, the value of equity, $\mathbf{E}(x)=\{E(x, s)\}_{s=1, \ldots, \mathcal{S}}$, is characterized by the following boundary value problem:

$$
\begin{aligned}
\mathbf{W}_{E} \mathbf{E}(x)= & (\mathbf{1}-\boldsymbol{\tau}) \odot\left(e^{x} \mathbf{1}-\mathbf{C}\right)+\mathbf{m} \odot[\mathbf{d}(x)-\mathbf{P}]+\mathbf{U E}^{\prime}(x)+\mathbf{V E}^{\prime \prime}(x) \\
& +\boldsymbol{\Delta}_{1} \mathbf{d}(x)-\mathbf{\Delta}_{2} \mathbf{P} \\
E\left(x_{D}(s), s\right)= & 0, \forall s=1, \ldots, \mathcal{S} \\
E_{x}\left(x_{D}(s), s\right)= & 0, \forall s=1, \ldots, \mathcal{S}
\end{aligned}
$$

where we define $\mathbf{W}_{E}=\operatorname{diag}(\mathbf{r})-\boldsymbol{\Pi}$. The matrices $\boldsymbol{\Delta}_{1}$ and $\boldsymbol{\Delta}_{2}$ summarize debt buy backs which occur in the 4 -state model when the state switches from $s_{4}$ to $s_{1}$. That is, in the 4 state model, $\boldsymbol{\Delta}_{1}$ is a 4 by 4 matrix that has a value of $\pi_{B}$ in entry 41 and zero elsewhere, and $\boldsymbol{\Delta}_{2}$ is a 4 by 4 matrix that has a value of $\pi_{B}$ in entry 44 and zero elsewhere; debt buy backs are not present in the 2 state model so that both $\boldsymbol{\Delta}_{1}$ and $\boldsymbol{\Delta}_{2}$ are zero matrices.

\footnotetext{
${ }^{18}$ The $i j$-th non-diagonal entry of $\boldsymbol{\Pi}$ is the risk neutral transition intensity from state $i$ to state $j$. The diagonal entries of $\boldsymbol{\Pi}$ are given by the negative row sums.
} 
Solutions. The derivation for the solutions are similar to those given in Chen (2010): both equity and debt will contain terms of the form $\omega \mathbf{z} e^{-\lambda x}$ where $\omega$ is a weighting scalar the pairs $(\lambda, \mathbf{z})$ are given by solutions to the following quadratic eigenvalue problem (QEP) of the form

$$
\mathbf{W} \mathbf{z}=-\lambda \mathbf{U} \mathbf{z}+\lambda^{2} \mathbf{V} \mathbf{z}
$$

with $\mathbf{W}$ set to $\mathbf{W}_{D}$ and $\mathbf{W}_{E}$, respectively, in the debt and equity solutions. There is a total of $2 \mathcal{S}$ solutions $\left(\lambda_{k}, \mathbf{z}_{k}\right)$ to (A.6), half of which have positive real parts with the other half having negative real parts (see Barlow, Rogers, and Williams (1980)). We discard the solutions with negative real parts as these correspond to explosive solutions.

Whereas the solutions in Jobert and Rogers (2006) and Chen (2010) only involve real eigenvalues, complex eigenvalues may show up for general transition intensities, and the remainder of this section will highlight the main differences in such situations. The complex eigenvalue solutions to (A.6) come in conjugate pairs $(\lambda, \mathbf{z})$ and $(\bar{\lambda}, \overline{\mathbf{z}})$. Since these solutions show up in the valuation equations with an additional weighting term $\omega$, we need only keep the real and complex parts to one of the conjugate pairs in our valuation equation (say the one with the positive complex part). For example, debt value has the form

$$
\begin{aligned}
\mathbf{D}(x)= & \mathbf{D}_{0}+\sum_{k=1}^{N_{D, \mathbb{R}}} \omega_{D, k}^{\mathbb{R}} \mathbf{D}_{1, k}^{\mathbb{R}} e^{-\lambda_{D, k}^{\mathbb{R}} x}+\sum_{k=1}^{N_{D, \mathbb{C}}^{+}} \omega_{D, k}^{\mathbb{C}, R e} \operatorname{Re}\left\{\mathbf{D}_{1, k}^{\mathbb{C}} e^{-\lambda_{D, k}^{\mathbb{C}} x}\right\} \\
& +\sum_{k=1}^{N_{D, \mathbb{C}}^{+}} \omega_{D, k}^{\mathbb{C}, I m} \operatorname{Im}\left\{\mathbf{D}_{1, k}^{\mathbb{C}} e^{-\lambda_{D, k}^{\mathbb{C}} x}\right\}
\end{aligned}
$$

where $\mathbf{D}_{0}$ is chosen to match the constant term in (A.1), the pairs $\left\{\left(\lambda_{D, k}^{\mathbb{R}}, \mathbf{D}_{1, k}^{\mathbb{R}}\right)\right\}_{k=1}^{N_{D, \mathbb{R}}}$ are the solutions to the QEP with real and positive eigenvalues, and the pairs $\left\{\left(\lambda_{D, k}^{\mathbb{C}}, \mathbf{D}_{1, k}^{\mathbb{C}}\right)\right\}_{k=1}^{N_{D, \mathbb{C}}^{+}}$are the solutions whose eigenvalues have both positive real and complex parts. Finally, there are $\mathcal{S}$ weights $\left\{\omega_{D, k}\right\}_{k=1}^{\mathcal{S}}=\left\{\omega_{D, k}^{\mathbb{R}}\right\}_{k=1}^{N_{D, \mathbb{R}}} \cup\left\{\omega_{D, k}^{\mathbb{C}, R e}\right\}_{k=1}^{N_{D, \mathbb{C}}^{+}} \cup\left\{\omega_{D, k}^{\mathbb{C}, I m}\right\}_{k=1}^{N_{D, \mathbb{C}}^{+}} \subset \mathbb{R}$ used to match $\mathcal{S}$ boundary value conditions (A.2).

The derivation for the equity solution is similar and is omitted for brevity.

\section{B Data}

\section{B.1 Variable Definition and Data Sources}

- tdebt (total debt): debt in current liability $(d l c)+$ long-term debt $(d l t t)$. Data source: COMPUSTAT Annual Industrial file.

- ldebt1y (the percentage of total debt that matures in more than 1 year): long-term debt $(d l t t) / t d e b t$. Data source: COMPUSTAT Annual Industrial file.

- ldebt2y (the percentage of total debt that matures in more than 2 years): (dltt - dd2) / 
tdebt. Data source: COMPUSTAT Annual Industrial file.

- ldebt3y (the percentage of total debt that matures in more than 3 years): (dltt $-d d 2-$ dd3) / tdebt. Data source: COMPUSTAT Annual Industrial file.

- ldebt4y (the percentage of total debt that matures in more than 4 years): (dltt - dd2$d d 3-d d 4) /$ tdebt. Data source: COMPUSTAT Annual Industrial file.

- ldebt5y (the percentage of total debt that matures in more than 5 years): (dltt - dd2 $d d 3-d d 4-d d 5) / t d e b t$. Data source: COMPUSTAT Annual Industrial file.

- $m k e$ (market value of equity): share price $\left(\operatorname{prcc}_{f}\right) \times$ common share outstanding $(c s h o)$. Data source: COMPUSTAT Annual Industrial file.

- bke (book value of equity): stockholders' equity (shareholder's equity (seq), if not available, common equity $(c e q)+$ par value of preferred shares (pstk), if not available, total asset $(a t)$ - total liability $(l t))+$ deferred tax and investment tax credit (txditc) book value of preferred shares (redemption value (pstkrv), if not available, liquidation value $(p s t k l)$, if not available, par value $(p s t k)$ ). Data source: COMPUSTAT Annual Industrial file.

- mkat (market value of total assets): (the market value of equity (mke) + the book value of total assets (at) - the book value of equity (bke) / GDP deflator, in logs. Data source: COMPUSTAT Annual Industrial file.

- abnearn (abnormal earning): (earnings in year $t+1$ (ibadj) - earnings in year $t$ ) / (share price $\left(\operatorname{prcc}_{f}\right) \times$ outstanding shares $(c s h p r i)$ in year $\left.t\right)$. Data source: COMPUSTAT Annual Industrial file.

- bklev (book leverage): total debt (debt in current liability $(d l c)+$ long-term debt $(d l t t)$ ) / assets (at). Data source: COMPUSTAT Annual Industrial file.

- mklev (market leverage): total debt (debt in current liability $(d l c)+$ long-term debt $(d l t t))$ / the market value of total assets (mkat, not in logs). Data source: COMPUSTAT Annual Industrial file.

- $m k 2 b k$ (market-to-book ratio): the market value of total assets (mkat, not in logs) / the book value of total assets (at). Data source: COMPUSTAT Annual Industrial file.

- profit (profitability): operating income before depreciation (oibdp) / assets (at). Data source: COMPUSTAT Annual Industrial file.

- profitvol (profit volatility): volatility of past 5 years of profit growth (operating income before depreciation in year $t(o i b d p)$ - operating income before depreciation in year $t-1)) / \operatorname{assets}(a t)$. Data source: COMPUSTAT Annual Industrial file.

- tangible (tangibility): gross property, plant, and equipment (ppent) / assets (at). Data source: COMPUSTAT Annual Industrial file. 
- assetmat (asset maturity): book value-weighted average of the maturities of property, plant and equipment and current assets, computed as (gross property, plant, and equipment $($ ppent $) /$ total assets $($ current assets $($ act $)+$ ppent $) \times($ gross property, plant, and equipment (ppent)/depreciation expense $(d p))+($ current assets $($ act $) /$ total assets $($ current assets $(a c t)+$ ppent $)) \times($ current assets $($ act $) /$ cost of goods sold $($ cogs $))$. Data source: COMPUSTAT Annual Industrial file.

- market beta (asset market beta): equity market beta computed using past 36 months of equity returns, which is then unlevered based on the Merton model (for details see Vassalou and Xing (2004) and Bharath and Shumway (2008)).

- bank beta (asset bank beta): equity bank beta (with respect to the banking industry portfolio) computed using past 36 months of equity returns, which is then unlevered based on the Merton model (for details see Acharya, Almeida, and Campello (2012)).

- tail beta (asset tail-risk beta): equity tail-risk beta defined as the ratio between (1) the firm average return from the days when the market had the $5 \%$ worst returns in the past year and (2) the average market return on the same days, which is then unlevered based on the Merton model (for details see Acharya, Almeida, and Campello (2012)).

- $c f$ beta (cash-flow beta): defined as the covariance between firm-level and aggregate cash flow changes (normalized by total assets (at) from the previous year) divided by the variance of aggregate cash flow changes; computed using at least 15 years of past 20 years of cash flow data $(i b)$.

\section{B.2 Calibrating the Non-default Spreads}

We compute the bond-CDS spread as the difference between the bond spread and the CDS spread for the same company at the same maturity. Transaction bond data between 2004 and 2010 are obtained from the Mergent Fixed Income Securities Database. The transaction data is merged with the Fixed Investment Securities Database (FISD) to obtain bond characteristic information, such as coopon rates, issue dates, maturity dates, and issue amounts. To compute the bond-CDS spread, we focus on senior-unsecured fixed-rate straight corporate bonds with semi-annual coupon payments. We keep bonds with investment grade ratings as Mergent's coverage of transactions on speculative grade bonds is small. We delete bonds with embedded options such as callable, puttable, and convertible. We also delete bonds with credit enhancement and less than one year to maturity. The corporate spread is computed as a parallel shift of the riskless zero curve, constructed from the libor-swap rates with maturity of 3 months to 10 years, such that the present value of future cash flows equals to the current bond price under the assumption of no default. The corresponding CDS spread with the same maturity is computed by interpolating CDS spreads with maturity of 6 months, 1 year, 2years, 3 years, 4 years, 5 years, 7 years and 10 years.

Before running regressions to investigate the relation between the bond-CDS spread and bond maturity, we need to address a possible sample selection bias in the sense that firms facing 
higher long-term liquidity spreads will choose to issue short-term bonds. Following Helwege and Turner (1999), we restrict the data to firms issuing both short-term bonds (maturity less than 3 years) and long-term bonds (maturity longer than 7 years) during the sample period. We run a regression of the bond-CDS spread on bond maturity, bond characteristics (bond age, issuing amount, and coupon rate), and firm characteristics (systematic beta, size, book leverage, market-to-book ratio, and profit volatility). Moreover, the relation between the bond-CDS spread and either bond maturity or systematic beta might change through business cycles. We add a recession dummy and its interaction with bond maturity and systematic beta in the regression. The regression results are present in Table A.1.

\section{Additional Robustness Checks}

We use the proportion of long-term debt that matures in more than 3 years as our benchmark measure of debt maturity in the paper. COMPUSTAT provides the information on the amount of debt that matures in years one through five, and more than five years. Based on these information, we can also construct numerical debt maturity. We obtain very similar results for the cross-sectional and panel regressions using the numerical debt maturity in the regression (these results are available upon request). The estimated coefficient on asset beta (with control for book leverage) implies that a one-standard deviation increase in asset beta lengthens firms' debt maturity by 6.7 months. We also obtain similar results using numerical debt maturity in the regression of the impact of business cycles on debt maturity.

To further examine the robustness of our results to different measures of debt maturity, we use the percentage of firms' total debt that matures in more than 1 year, 2 years, 4 years, and 5 years as maturity proxies in the regression. The results are presented in Table A.3. First, we find a similar impact of macroeconomic conditions and asset beta on various long-term debt share measures. Worsening macroeconomic conditions and lower asset betas are associated with shorter debt maturities. Second, high systematic risk firms reduce their debt maturities more from expansions to recessions than low systematic risk firms.

To investigate whether our findings are sensitive to the 2008 financial crisis, we run regressions using data in the period: 1974-2006. Excluding the last four years (2007-2010) of data enable us to examine whether our results are driven by the largest financial crisis since the Great Depression in the 1930s. The results using long-term debt share and numerical debt maturity measures are presented in Table A.4. We obtain quantitatively similar and slightly more significant results by excluding the last four years of data. Coefficient estimates for both the recession dummy, asset betas and their interaction terms are statistically significant in all the specifications. Worsening macroeconomic conditions are associated with shortening debt maturities and high exposure to systematic risk are associated with long debt maturities. In addition, the negative relation between the impact of business cycles on debt maturity and firms' asset betas that we find in the entire sample also exist in the sub-sample period. In fact, all the interaction terms between various asset betas and macroeconomic variables

are statistically significant across all specifications. The results show that a firm with high systematic risk exposure has a more stable debt maturity over the business cycles. 
Table A.1: Liquidity Spread and Bond Maturity. This table presents regression results of the bond-CDS spread on a recession dummy, debt maturity, asset beta, interactions between the recession dummy and debt maturity and between the recession dummy and asset beta, bond characteristics (bond age, issuing amount, and coupon rate), and firm controls (firm size, book leverage, market-to-book ratio, and profit volatility). We restrict the sample to firms that have issued both short-term bonds (maturity less than 3 years) and long-term bonds (maturity longer than 7 years) in the period of $2004-2010$. We adjust standard errors by clustering the observations at the bond issue level. Robust t-statistics are presented in parentheses below parameter estimates. Significance at the $10 \%, 5 \%$, and $1 \%$ levels is indicated by *,**, ***, respectively.

\begin{tabular}{|c|c|c|c|c|}
\hline & (1) & (2) & (3) & (4) \\
\hline rec & $\begin{array}{l}-0.147 \\
(-1.23)\end{array}$ & $\begin{array}{l}-0.332^{*} \\
(-2.06)\end{array}$ & $\begin{array}{l}-0.457^{* * *} \\
(-3.20)\end{array}$ & $\begin{array}{l}-0.169 \\
(-1.28)\end{array}$ \\
\hline bondmat & $\begin{array}{l}0.014^{*} \\
(1.72)\end{array}$ & $\begin{array}{l}0.019^{* *} \\
(2.15)\end{array}$ & $\begin{array}{l}0.020^{* *} \\
(2.27)\end{array}$ & $\begin{array}{l}0.024^{* * *} \\
(3.38)\end{array}$ \\
\hline bondmat $\times$ rec & $\begin{array}{l}0.161^{* * *} \\
(3.61)\end{array}$ & $\begin{array}{l}0.163^{* * *} \\
(4.09)\end{array}$ & $\begin{array}{l}0.168^{* * *} \\
(4.90)\end{array}$ & $\begin{array}{l}0.188^{* * *} \\
(3.85)\end{array}$ \\
\hline market beta & $\begin{array}{l}0.185^{* * *} \\
(2.93)\end{array}$ & & & \\
\hline market beta $\times$ rec & $\begin{array}{l}0.460^{* *} \\
(2.55)\end{array}$ & & & \\
\hline bank beta & & $\begin{array}{l}0.028 \\
(0.33)\end{array}$ & & \\
\hline bank beta $\times$ rec & & $\begin{array}{l}1.269^{* * *} \\
(2.99)\end{array}$ & & \\
\hline tail beta & & & $\begin{array}{l}0.051 \\
(0.57)\end{array}$ & \\
\hline tail beta $\times$ rec & & & $\begin{array}{l}0.641^{* * *} \\
(4.41)\end{array}$ & \\
\hline cfbeta & & & & $\begin{array}{l}-0.139^{* * *} \\
(-2.98)\end{array}$ \\
\hline cfbeta $\times$ rec & & & & $\begin{array}{l}0.054 \\
(1.05)\end{array}$ \\
\hline bondage & $\begin{array}{l}-0.001 \\
(-0.10)\end{array}$ & $\begin{array}{l}-0.014 \\
(-1.16)\end{array}$ & $\begin{array}{l}-0.004 \\
(-0.37)\end{array}$ & $\begin{array}{l}-0.017^{*} \\
(-1.92)\end{array}$ \\
\hline issueamt & $\begin{array}{l}0.024 \\
(1.32)\end{array}$ & $\begin{array}{l}-0.002 \\
(-0.12)\end{array}$ & $\begin{array}{l}0.001 \\
(0.04)\end{array}$ & $\begin{array}{l}-0.010 \\
(-0.61)\end{array}$ \\
\hline coupon & $\begin{array}{l}0.037 \\
(1.33)\end{array}$ & $\begin{array}{l}0.075^{* *} \\
(2.21)\end{array}$ & $\begin{array}{l}0.047 \\
(1.58)\end{array}$ & $\begin{array}{l}0.074^{* * *} \\
(3.65)\end{array}$ \\
\hline mkat & $\begin{array}{l}-0.016 \\
(-0.24)\end{array}$ & $\begin{array}{l}-0.068 \\
(-1.04)\end{array}$ & $\begin{array}{l}-0.034 \\
(-0.41)\end{array}$ & $\begin{array}{l}0.448^{* *} \\
(2.38)\end{array}$ \\
\hline bklev & $\begin{array}{l}1.650^{* *} \\
(2.28)\end{array}$ & $\begin{array}{l}0.942 \\
(1.42)\end{array}$ & $\begin{array}{l}1.103 \\
(1.09)\end{array}$ & $\begin{array}{l}1.669^{*} \\
(1.71)\end{array}$ \\
\hline mk2bk & $\begin{array}{l}-0.035 \\
(-1.31)\end{array}$ & $\begin{array}{l}-0.040 \\
(-1.23)\end{array}$ & $\begin{array}{l}-0.047 \\
(-1.36)\end{array}$ & $\begin{array}{l}-0.207^{* * *} \\
(-2.82)\end{array}$ \\
\hline profitvol & $\begin{array}{l}4.153^{*} \\
(1.76)\end{array}$ & $\begin{array}{l}6.724^{* *} \\
(2.56)\end{array}$ & $\begin{array}{l}6.340^{*} \\
(2.02)\end{array}$ & $\begin{array}{l}29.000^{* * * *} \\
(3.16)\end{array}$ \\
\hline Constant & $\begin{array}{l}-0.732 \\
(-0.94)\end{array}$ & $\begin{array}{l}-0.059 \\
(-0.08)\end{array}$ & $\begin{array}{l}-0.365 \\
(-0.38)\end{array}$ & $\begin{array}{l}-5.483^{* *} \\
(-2.61)\end{array}$ \\
\hline Observations & 955 & 955 & 955 & 1,013 \\
\hline$R^{2}$ & 0.441 & 0.440 & 0.418 & 0.407 \\
\hline
\end{tabular}


Table A.2: Firm Characteristics and the Impact of Business Cycles. This table presents regression results of the fraction of debt that matures in more than 3 years on a recession dummy, firm characteristic (asset beta, total asset volatility, firm size, abnormal earning, book leverage, market-to-book ratio, asset maturity, and profit volatility), an interaction between the dummy variable and each firm variable, and industry dummies. We also include either a quadratic time trend or an aggregate trend generated by the H-P filter on the aggregate long-term debt share. Standard errors are adjusted by clustering the observations at the industry level. Robust t-statistics are presented in parentheses below parameter estimates. Significance at the $10 \%, 5 \%$, and $1 \%$ levels is indicated by $*, * *, * * *$, respectively.

\begin{tabular}{|c|c|c|}
\hline & (1) & (2) \\
\hline rec & $\begin{array}{l}0.012 \\
(0.60)\end{array}$ & $\begin{array}{l}0.023 \\
(1.13)\end{array}$ \\
\hline market beta & $\begin{array}{l}0.044^{* * *} \\
(8.61)\end{array}$ & $\begin{array}{l}0.040^{* * *} \\
(7.75)\end{array}$ \\
\hline market beta $\times$ rec & $\begin{array}{l}0.017^{*} \\
(1.93)\end{array}$ & $\begin{array}{l}0.018^{*} \\
(1.96)\end{array}$ \\
\hline mkat & $\begin{array}{l}0.044^{* * *} \\
(15.92)\end{array}$ & $\begin{array}{l}0.043^{* * *} \\
(16.66)\end{array}$ \\
\hline mkat $\times$ rec & $\begin{array}{l}-0.006^{* * *} \\
(-2.64)\end{array}$ & $\begin{array}{l}-0.005^{* *} \\
(-2.23)\end{array}$ \\
\hline abnearn & $\begin{array}{l}-0.011^{*} \\
(-1.93)\end{array}$ & $\begin{array}{l}-0.010 \\
(-1.59)\end{array}$ \\
\hline abnearn $\times$ rec & $\begin{array}{l}-0.013 \\
(-0.85)\end{array}$ & $\begin{array}{l}-0.021 \\
(-1.39)\end{array}$ \\
\hline bklev & $\begin{array}{l}0.312^{* * *} \\
(13.61)\end{array}$ & $\begin{array}{l}0.308^{* * *} \\
(13.38)\end{array}$ \\
\hline bklev $\times$ rec & $\begin{array}{l}-0.045 \\
(-1.51)\end{array}$ & $\begin{array}{l}-0.062^{* *} \\
(-2.10)\end{array}$ \\
\hline $\mathrm{mk} 2 \mathrm{bk}$ & $\begin{array}{l}-0.036^{* * *} \\
(-5.26)\end{array}$ & $\begin{array}{l}-0.035^{* * *} \\
(-4.98)\end{array}$ \\
\hline $\mathrm{mk} 2 \mathrm{bk} \times \mathrm{rec}$ & $\begin{array}{l}0.015^{*} \\
(1.86)\end{array}$ & $\begin{array}{l}0.012 \\
(1.48)\end{array}$ \\
\hline assetmat & $\begin{array}{l}0.007^{* * *} \\
(7.13)\end{array}$ & $\begin{array}{l}0.007^{* * *} \\
(7.12)\end{array}$ \\
\hline assetmat $\times$ rec & $\begin{array}{l}0.000 \\
(0.16)\end{array}$ & $\begin{array}{l}0.000 \\
(0.52)\end{array}$ \\
\hline profitvol & $\begin{array}{l}-0.301^{* * *} \\
(-4.09)\end{array}$ & $\begin{array}{l}-0.330^{* * *} \\
(-4.60)\end{array}$ \\
\hline profitvol $\times$ rec & $\begin{array}{l}0.017 \\
(0.15)\end{array}$ & $\begin{array}{l}0.015 \\
(0.14)\end{array}$ \\
\hline mertondd & $\begin{array}{l}0.007^{* * *} \\
(6.92)\end{array}$ & $\begin{array}{l}0.006^{* * *} \\
(6.36)\end{array}$ \\
\hline mertondd $\times$ rec & $\begin{array}{l}-0.003^{* *} \\
(-2.29)\end{array}$ & $\begin{array}{l}-0.005^{* * *} \\
(-3.54)\end{array}$ \\
\hline Quadratic Trend & Yes & No \\
\hline Aggregate Trend & No & Yes \\
\hline Industry-Fixed Effect & Yes & Yes \\
\hline Observations & 39,509 & 39,509 \\
\hline$R^{2}$ & 0.148 & 0.148 \\
\hline
\end{tabular}


Table A.3: Alternative Measures of Long-Term Debt Share. This table presents regression results of various measures of long-term debt share (ldebt1y, ldebt2y, ldebt4y, and ldebt5y) on a recession dummy, asset beta, an interaction between the recession dummy and asset beta, firm controls (total asset volatility, firm size, abnormal earning, book leverage, market-to-book ratio, asset maturity, and profit volatility), industry dummies and a quadratic time trend. We adjust standard errors by clustering the observations at the industry level. Robust t-statistics are presented in parentheses below parameter estimates. Significance at the $10 \%, 5 \%$, and $1 \%$ levels is indicated by $*, * *, * * *$, respectively.

\begin{tabular}{|c|c|c|c|c|c|c|}
\hline \multirow[b]{2}{*}{ rec } & \multicolumn{3}{|c|}{ ldebt1y } & \multicolumn{3}{|c|}{ ldebt2y } \\
\hline & $\begin{array}{l}-0.032^{* * *} \\
(-5.42)\end{array}$ & $\begin{array}{l}-0.027^{* * *} \\
(-4.56)\end{array}$ & $\begin{array}{l}-0.028^{* * *} \\
(-4.94)\end{array}$ & $\begin{array}{l}-0.042^{* * *} \\
(-5.42)\end{array}$ & $\begin{array}{l}-0.034^{* * *} \\
(-5.39)\end{array}$ & $\begin{array}{l}-0.034^{* * *} \\
(-5.79)\end{array}$ \\
\hline market beta & $\begin{array}{l}0.041^{* * *} \\
(9.96)\end{array}$ & & & $\begin{array}{l}0.049^{* * *} \\
(11.79)\end{array}$ & & \\
\hline market beta $\times$ rec & $\begin{array}{l}0.021^{* * *} \\
(3.89)\end{array}$ & & & $\begin{array}{l}0.028^{* * *} \\
(3.37)\end{array}$ & & \\
\hline bank beta & & $\begin{array}{l}0.039^{* * *} \\
(11.54)\end{array}$ & & & $\begin{array}{l}0.047^{* * *} \\
(8.71)\end{array}$ & \\
\hline bank beta $\times$ rec & & $\begin{array}{l}0.029 * * * \\
(2.91)\end{array}$ & & & $\begin{array}{l}0.036^{* * *} \\
(3.18)\end{array}$ & \\
\hline tail beta & & & $\begin{array}{l}0.034^{* * *} \\
(10.66)\end{array}$ & & & $\begin{array}{l}0.042^{* * *} \\
(12.00)\end{array}$ \\
\hline tail beta $\times$ rec & & & $\begin{array}{l}0.018^{* * * *} \\
(2.64)\end{array}$ & & & $\begin{array}{l}0.020^{* * *} \\
(2.95)\end{array}$ \\
\hline Quadratic Trend & Yes & Yes & Yes & Yes & Yes & Yes \\
\hline Firm Controls & Yes & Yes & Yes & Yes & Yes & Yes \\
\hline Industry Fixed-Effect & Yes & Yes & Yes & Yes & Yes & Yes \\
\hline Observations & 51,812 & 51,812 & 51,644 & 42,919 & 42,919 & 42,786 \\
\hline \multirow[t]{2}{*}{$R^{2}$} & 0.107 & 0.103 & 0.104 & 0.135 & 0.132 & 0.134 \\
\hline & & ldebt4y & & & ldebt5y & \\
\hline rec & $\begin{array}{l}-0.045^{* * *} \\
(-5.94)\end{array}$ & $\begin{array}{l}-0.044^{* * *} \\
(-6.35)\end{array}$ & $\begin{array}{l}-0.033^{* * *} \\
(-5.96)\end{array}$ & $\begin{array}{l}-0.042^{* * *} \\
(-5.86)\end{array}$ & $\begin{array}{l}-0.037^{* * *} \\
(-5.71)\end{array}$ & $\begin{array}{l}-0.034^{* * *} \\
(-6.75)\end{array}$ \\
\hline market beta & $\begin{array}{l}0.038^{* * *} \\
(8.26)\end{array}$ & & & $\begin{array}{l}0.032^{* * *} \\
(7.29)\end{array}$ & & \\
\hline market beta $\times$ rec & $\begin{array}{l}0.023^{* *} \\
(2.46)\end{array}$ & & & $\begin{array}{l}0.023^{* * *} \\
(2.74)\end{array}$ & & \\
\hline bank beta & & $\begin{array}{l}0.035^{* * *} \\
(5.56)\end{array}$ & & & $\begin{array}{l}0.034^{* * *} \\
(6.02)\end{array}$ & \\
\hline bank beta $\times$ rec & & $\begin{array}{l}0.039^{* * *} \\
(3.02)\end{array}$ & & & $\begin{array}{l}0.031^{* *} \\
(2.58)\end{array}$ & \\
\hline tail beta & & & $\begin{array}{l}0.037^{* * *} \\
(10.40)\end{array}$ & & & $\begin{array}{l}0.027^{* * *} \\
(7.79)\end{array}$ \\
\hline tail beta $\times$ rec & & & $\begin{array}{l}0.008 \\
(1.19)\end{array}$ & & & $\begin{array}{l}0.015^{* *} \\
(2.35)\end{array}$ \\
\hline Quadratic Trend & Yes & Yes & Yes & Yes & Yes & Yes \\
\hline Firm Controls & Yes & Yes & Yes & Yes & Yes & Yes \\
\hline Industry Fixed-Effect & Yes & Yes & Yes & Yes & Yes & Yes \\
\hline Observations & 42,919 & 42,919 & 42,786 & 42,919 & 42,919 & 42,786 \\
\hline$R^{2}$ & 0.156 & 0.154 & 0.156 & 0.154 & 0.153 & 0.152 \\
\hline
\end{tabular}


Table A.4: Sample Period 1974-2006 (Excluding the Financial Crisis). This table presents regression results of the fraction of debt that matures in more than 3 years on a recession dummy, asset beta, an interaction between the recession dummy with asset beta, firm controls (total asset volatility, firm size, abnormal earning, book leverage, market-to-book ratio, asset maturity, and profit volatility), industry dummies and a quadratic time trend. The sample period is 1974 to 2006 . We adjust standard errors by clustering the observations at the industry level. Robust t-statistics are presented in parentheses below parameter estimates. Significance at the $10 \%, 5 \%$, and $1 \%$ levels is indicated by ${ }^{*},{ }^{* *},{ }^{* *}$, respectively.

\begin{tabular}{|c|c|c|c|c|c|c|}
\hline & \multicolumn{3}{|c|}{ Long-term debt share } & \multicolumn{3}{|c|}{ Numerical debt maturity } \\
\hline & (1) & $(2)$ & $(3)$ & (4) & (5) & (6) \\
\hline rec & $\begin{array}{l}-0.052^{* * *} \\
(-6.98)\end{array}$ & $\begin{array}{l}-0.053^{* * *} \\
(-7.48)\end{array}$ & $\begin{array}{l}-0.039^{* * *} \\
(-6.17)\end{array}$ & $\begin{array}{l}-0.433^{* * *} \\
(-7.01)\end{array}$ & $\begin{array}{l}-0.441^{* * *} \\
(-7.17)\end{array}$ & $\begin{array}{l}-0.342^{* * *} \\
(-7.11)\end{array}$ \\
\hline market beta & $\begin{array}{l}0.048^{* * * *} \\
(9.99)\end{array}$ & & & $\begin{array}{l}0.387^{* * *} \\
(8.78)\end{array}$ & & \\
\hline market beta $\times$ rec & $\begin{array}{l}0.033^{* * *} \\
(4.17)\end{array}$ & & & $\begin{array}{l}0.278^{* * *} \\
(4.18)\end{array}$ & & \\
\hline bank beta & & $\begin{array}{l}0.043^{* * *} \\
(6.90)\end{array}$ & & & $\begin{array}{l}0.380^{* * *} \\
(7.47)\end{array}$ & \\
\hline bank beta $\times$ rec & & $\begin{array}{l}0.058^{* * *} \\
(4.71)\end{array}$ & & & $\begin{array}{l}0.481^{* * *} \\
(4.62)\end{array}$ & \\
\hline tail beta & & & $\begin{array}{l}0.041 \text { *** } \\
(10.65)\end{array}$ & & & $\begin{array}{l}0.329 * * * \\
(10.31)\end{array}$ \\
\hline tail beta $\times$ rec & & & $\begin{array}{l}0.017^{* *} \\
(2.36)\end{array}$ & & & $\begin{array}{l}0.179^{* * *} \\
(3.10)\end{array}$ \\
\hline Quadratic Trend & Yes & Yes & Yes & Yes & Yes & Yes \\
\hline Firm Controls & Yes & Yes & Yes & Yes & Yes & Yes \\
\hline Industry Fixed-Effect & Yes & Yes & Yes & Yes & Yes & Yes \\
\hline Observations & 40,170 & 40,170 & 40,040 & 37,658 & 37,658 & 37,535 \\
\hline$R^{2}$ & 0.155 & 0.152 & 0.153 & 0.165 & 0.162 & 0.163 \\
\hline
\end{tabular}

